
CREST Working Paper

\begin{tabular}{|c|}
\hline $\begin{array}{c}\text { A Cross-Country Comparison } \\
\text { of Seasonal Cycles and } \\
\text { Business Cycles } \\
\text { Jeffrey A. Miron } \\
\text { November, } 1988 \\
89-07\end{array}$ \\
\hline
\end{tabular}





\title{
A Cross Country Comparison of Seasonal Cycles and Business Cycles
}

\author{
Jeffrey A. Miron \\ University of Michigan and NBER
}

November, 1988

I thank Todd Clark for research assistance and David Cutler, David Weil, Steve Zeldes, and seminar participants at Harvard, Yale, Brown, Columbia, Johns Hopkins, Ohio State, Illinois, Penn, Berkeley, Rochester, MIT, Boston University and the NBER Macro Lunch Group for comments on an earlier draft. Financial support from NSF Grant SES-8710140 is gratefully acknowledged. 



\section{Introduction}

International comparisons of business cycles have been an important component of research on aggregate fluctuations since the seminal work of Wesley C. Mitchell in 1927. Indeed, the striking similarity of business cycles across countries documented by early business cycle analysts (Mitchell (1927), Burns and Mitchell (1946)) constituted the prime impetus to theoretical and later empirical research on business cycles, that is, to the establishment of business cycles as a key topic for economic research. ${ }^{1}$ As Lucas (1977) emphasized eloquently 50 years after Mitchell's original work, it is the fact that key observations about aggregate variables are so consistent across countries and time periods that "suggests the possibility of a unified explanation of business cycles."

This paper conducts a cross country analysis of the seasonal cycles in aggregate economic activity, and it compares the cross country variation in the properties of seasonal cycles to the cross country variation in the properties of business cycles. Seasonal fluctuations account for a large fraction (80-90\%) of the non-trend variation in most aggregate quantity variables, but there has been almost no analysis of seasonal fluctuations in the literature on international comparisons of aggregate fluctuations. ${ }^{2}$ In fact, the pioneers of the research on international comparisons of business cycles also invented seasonal adjustment techniques (Macaulay (1938), Mitchell (1927), Burns and Mitchell (1946)), and they generally believed that "to isolate cyclical fluctuations for close study, we should be able to determine ... the presence or absence of seasonal variations ... and ... to get rid of them when we wish." (Mitchell $(1927, \mathrm{p} .236))$ By contrast, this paper argues that comparisons of seasonal cycles across countries and comparisons of seasonal cycles with business cycles can shed considerable light on the nature of all kinds of aggregate fluctuations. The key

1 For more recent evidence of the similarity of business cycles across countries, see Backus and Kehoe (1988), Gerlach (1988) and Baxter and Stockman (1988). In addition to demonstrating the similarity of business cycles across countries, international comparisons of business cycles have shown that the timing of peaks and troughs in economic activity is highly correlated across countries, with the strength of this correlation increasing over time (Mitchell (1927), Morgenstern (1959), and Backus and Kehoe (1988)).

2 The exceptions have focused mainly on interest rates and exchange rates. See, for example, Kemmerer (1910), Morgenstern (1959), and Clark (1984). 
finding in the paper is that the amount of seasonal variation in aggregate variables is strongly correlated across countries with the amount of business cycle variation.

The paper proceeds in three steps. Section 3 presents the seasonal patterns in aggregate variables for over twenty-five countries. The results show that the main features of the seasonal patterns in most countries (including those in the Southern Hemisphere) are the same as those in the United States, implying a world wide seasonal cycle in aggregate economic activity. The major features of the world wide seasonal pattern are a fourth quarter boom in output (including consumption, investment and government purchases); a third quarter trough in manufacturing production; and a first quarter trough in all economic activity. In addition, the money stock displays a fourth quarter peak and first quarter trough all over the world, while prices and real and nominal interest rates are essentially aseasonal in all countries. This section also shows that, in all countries and at both seasonal and business cycle frequencies, output movements across sectors are highly correlated, nominal money and real output move together, labor productivity is procyclical, and prices vary less than quantities. Thus, the finding in Barsky and Miron (1988) that the seasonal cycle displays the important qualitative properties of the business cycle is robust across a broad range of countries.

The second part of the paper (Section 4) shows that the countries that exhibit substantial seasonal variation are also the ones that exhibit substantial business cycle variation. I estimate cross sectional regressions that relate the amount of business cycle variation to the amount of seasonal variation and other country characteristics. These characteristics include measures of the degree of economic diversity, of the industrial composition of output, and of the level of economic development. I show that there is a strong correlation across countries between the amount of seasonal variation exhibited by a country and the amount of business cycle variation exhibited by that country, even after controlling for these other country characteristics.

In Section 5 of the paper I examine a simple model in which the amounts of seasonal and non- 
seasonal variation in the endogenous variables are correlated across countries. The key assumption of the model is that the mechanism relating exogenous shocks to endogenous variables is similar across seasonal and cyclical frequencies. Interpreted in light of this model, the facts presented in Section 4 therefore suggest that the mechanisms operative in actual economies in producing business cycle fluctuations are similar to those producing seasonal fluctuations.

Section 6 concludes the paper.

\section{Estimation Strategy}

The statistical approach that I use to analyze seasonal fluctuations is the same as that in Barsky and Miron (1988), so I outline the approach only briefly here. I focus on deterministic rather than stochastic seasonality because of two considerations, one empirical, the other theoretical. The empirical consideration is that seasonal dummies account for most of the seasonal variation in the data; stochastic seasonality appears to play a minor role. The theoretical consideration is that stationary, stochastic models of seasonality are unlikely to properly account for the seasonal variation in economic variables because the long-run forecasts of such models are independent of the season being forecast, i.e., they do not imply that Christmas falls in December year after year.

Let $X_{t}$ be a time series of interest. I am interested in examining the seasonal behavior of $X_{t}$, after accounting for its secular behavior. The procedure that I use to account for long term growth in $X_{t}$ is to calculate its $\log$ growth rate. An alternative procedure would be to detrend $\ln X_{t}$, either by deterministic time trends or by a flexible procedure such as that in Hodrick and Prescott (1980). The results in Barsky and Miron (1988), however, indicate that the important conclusions about seasonal fluctuations in the United States are robust to the method of detrending, so it is unlikely that this consideration affects the results presented here. ${ }^{3}$ In general, the log growth rate of a series

3 Baxter and Stockman (1988) do find that the choice of detrending method has significant effects on their conclusions regarding stylized facts at business cycle frequencies. Their results are more susceptible to the choice of detrending procedure because they focus on business cycle frequencies rather than seasonal frequencies. The three different detrending procedures eliminate different amounts of business cycle variation, but they imply roughly equivalent seasonal patterns in most cases. 
is stationary whether its secular component is due to a deterministic time trend or to a unit root. ${ }^{4}$

Now let $x_{t}$ be the log growth rate of $X_{t}$. I assume that $x_{t}$ can be described as the sum of deterministic seasonals and a stationary moving average process:

$$
x_{t}=\sum_{s=1}^{S} \xi_{s} d_{t}^{s}+\beta(L) \epsilon_{t}
$$

where $\beta(L)$ is a polynomial in the lag operator, $d_{t}^{s}$ is a seasonal dummy for season $s, S$ is the number of seasons, $\xi_{s}$ is a coefficient, $\epsilon_{t}$ is white noise, and the polynomial $\beta(L)$ satisfies $\sum_{i=0}^{\infty} \beta_{i}^{2}<\infty$. This specification allows for both deterministic and stochastic seasonality in $x_{t}$. If the seasonal dummy coefficients are not all identical, then the series displays deterministic seasonality. If the polynomial $\beta(L)$ implies a quantitatively important $S t h$ order autocorrelation in the non-seasonal dummy component of $x_{t}$, then the series displays stochastic seasonality. ${ }^{5}$ It is possible for a series to display both deterministic and stochastic seasonality (Pierce (1978)).

In order to examine the seasonal variation in economic times series, I examine the deterministic seasonals, i.e., the regular seasonal peaks and troughs in the series. For this purpose I estimate the equation

$$
x_{t}=\sum_{s=1}^{S} \xi_{s} d_{t}^{s}+\eta_{t}
$$

where $\eta_{t}$ is the stochastic component of $x_{t}$. Ordinary Least Squares estimates of the seasonal dummy coefficients are consistent. ${ }^{6}$ The error term in this equation, which is the stochastic component of $x_{t}$, need not be serially uncorrelated, however, so the OLS standard errors are not appropriate. I apply the Hansen and Hodrick (1980) technique, as modified by Newey and West (1987), to obtain standard errors that are consistent even in the presence of a non-white noise error term. ${ }^{7}$

4 See, for example, Nelson and Plosser (1982) and Campbell and Mankiw (1986) for discussions of trends versus unit roots in macroeconomic time series.

5 As long as $\beta(L)$ can be infinite order, the model in (1) is consistent with any stationary ARMA model for the stochastic seasonality in $x_{t}$.

6 OLS estimates of this model are also asymptotically efficient (Fuller (1976), pp.388-93), so for samples of the size I employ here there is probably little gain to estimating the model by Generalized Least Squares.

7 This procedure for calculating standard errors assumes that there is no unit root in the stochastic component of $\Delta \ln X_{t}$. This assumption is likely violated if the secular growth in $\ln X_{t}$ is due to a deterministic time trend rather than a unit root. 
To examine the relation between variables at seasonal frequencies, I estimate an instrumental variables regression with seasonal dummies as the only instruments. This procedure produces the same coefficient estimate on the right-hand side variable as regressing the seasonal dummy pattern in one series on the seasonal dummy pattern in the other series, but it produces a standard error for this coefficient estimate that reflects the sample size used in estimating the two seasonal dummy patterns. Again, I correct the standard errors from this procedure to account for the fact that the error term may not be white noise.

\section{The Seasonal Patterns in Aggregate Variables Across Countries}

This section presents the seasonal patterns in quarterly and monthly macroeconomic time series for a large number of countries. The objectives are to determine whether the seasonal patterns are similar across countries and whether the cross-correlation properties of aggregrate variables at seasonal frequencies are similar to their properties at business cycle frequencies. The selection of countries and time series is governed by the availability of data. I have conducted a search for seasonally unadjusted data for all countries, and I report results below for any country for which I found data series of reasonable length and quality. In general I report monthly results if such data are available and quarterly results otherwise. ${ }^{8}$ The main caveat regarding interpretation of the results is that, because I have relied on a number of different sources, the definitions and/or reliability of the data series may differ across countries. Appendix A provides details of the construction of the data set.

\subsection{The Seasonal Patterns in Quarterly and Monthly Series}

Tables 1-9 present results for quarterly and monthly times series in over twenty-five countries. All of the results are computed from regressions such as (2). The summary statistics are the

8 The only exceptions to this statement are the results for hours and employment. Monthly employment and hours data are available for a few countries, but I have reported quarterly results only. 
standard deviation of the fitted values of this regression, which is an estimate of the variability of the deterministic seasonal component of the series; the standard deviation of the residual, which is an estimate of the variability of the business cycle plus stochastic seasonal component of the series; and the $R^{2}$ of the regression, which is an estimate of the fraction of the variation in each series explained by deterministic seasonals. The entries in the last four (twelve) columns of the tables are the estimated coefficients on the seasonal dummies. The overall mean of the dependent variable has been subtracted from each coefficient, so they are interpreted as the difference between the average growth rate by quarter (month) and the overall average growth rate. The growth rates are measured at either quarterly or monthly rates.

Before turning to examination of the seasonal patterns themselves, it is useful to consider the quantitative importance of seasonal dummies in explaining the total variation in these variables. Deterministic seasonals account for a striking amount of the total variation in quarterly real GDP (typically more than $80 \%$ and often more than $90 \%$ ), monthly industrial production (70-90\%), and monthly retail sales $(80-90 \%) .^{9}$ The dummies are also important in explaining the monthly variation in the money stock (50-80\%) and the quarterly variation in employment and manufacturing hours $(50-90 \%) \cdot{ }^{10,11}$

Seasonal dummies are not important determinants of the price level or nominal or real interest rates. ${ }^{12}$ The absolute magnitudes of the seasonal fluctuations in these variables are extremely small, and seasonal dummies explain a relatively small fraction (usually less than $10 \%$ ) of the total

9 I examine GDP, rather than GNP, because GDP is available for a much larger number of countries. GDP equals GNP less net factor payments from abroad. For the countries for which GDP and GNP are both available I have verified that the results reported in the paper are similar for the two series.

10 As shown in Appendix Tables B1-B2, dummies explain an extremely large fraction of the variation in consumption and fixed investment. Seasonal dummies are also important in explaining government purchases, exports and imports, but less so than for consumption and investment (Tables B3-B5).

11 The exact amount of variation attributable to seasonal dummies depends, of course, on the choice of detrending technique. Generally the first difference filter implies the largest role for dummies, the Hodrick and Prescott (1980) filter the second largest, and linear or quadratic detrending the smallest.

12 The nominal interest rate results are calculated for the change in $\ln \left(1+i_{t}\right)$ while those for the real rate are calculated for the level of $\ln \left(1+i_{t}\right)-\ln \left(1+\pi_{t}\right)$, where $\pi_{t}$ is the inflation rate over the horizon of the nominal rate. This horizon varies from one to three months depending on the country. See Appendix $A$ for details. 
variation. The results do suggest a slightly greater role for seasonal variation in the price level than the quarterly results in Barsky and Miron (1988): in seven of the twenty-one countries for which data are available, dummies explain at least twenty percent of the variation in prices, and in one country (Greece) the dummies explain $50 \%$ of the total variation. Nevertheless, the amount of the seasonal dummy variation in prices or interest rates is always small in comparison to that in quantities.

Table 1 shows that the pattern of seasonal variation in real GDP is strikingly similar across countries. Output falls sharply from the fourth quarter to the first quarter, grows strongly from the first to the second quarter, grows further going into the third quarter, and peaks in the fourth quarter. There are, of course, some exceptions to this general pattern. In three countries (Australia, Japan, Sweden), output does not recover in the second quarter but remains at approximately its low first quarter level. In some countries output does not change much from the second to the third quarter (Argentina, Italy, United States), and in three countries (Netherlands, Sweden, Taiwan) output falls significantly in the third quarter. Finally, output declines strongly in the fourth quarter in Canada and declines weakly in Germany. Nevertheless, there is a great deal of similarity across countries, particularly the fourth quarter increases and first quarter declines. There appears to be a "world seasonal" in aggregate economic activity. ${ }^{13}$

The seasonal patterns in (real) retail sales are presented in Table $2 .^{14}$ The most dramatic

13 Appendix B shows the seasonal patterns in consumption, investment, government purchases, exports and imports. Both consumption and investment decline strongly in the first quarter in all countries except Taiwan, where consumption grows in the first quarter. Consumption grows strongly going from the first quarter to the second quarter in all countries except Italy, Taiwan and Argentina. The important differences across countries occur in the investment category, in quarters other than the first quarter. Many countries show strong recoveries in the second quarter, but some show significant further declines from the first quarter levels. There are also contrasts in the third and fourth quarters. In the fourth quarter, for example, investment in Sweden grows strongly while investment in Canada declines significantly. Government purchases, exports and imports all exhibit seasonal patterns similar to the one described for overall GDP. All three variables fall substantially from the fourth quarter to the first quarter and grow substantially from the third quarter to the fourth quarter in most countries. Thus, the similarity of seasonal cycles across countries is present in all major components of GDP.

14 Monthly data on the price level are not available for Australia or New Zealand, so the results reported for these two countries are for nominal retail sales. Given the widespread absence of season ality in prices demonstrated in Table 5 below, it is unlikely that the failure to correct these series for price fluctuations has a significant effect on the estimated seasonal patterns. Quarterly results on the price level for these two countries do not reveal evidence of significant seasonality. I do not include retail sales data for these two countries in the cross 
and consistent feature of the seasonal patterns in retail sales is the large positive growth rate in December followed by the large negative growth rate in January. In most countries the average rate of increase of retail sales in December is at least $20 \%$, and the average rate of decrease from December to January is at least $30 \%$. The only country that fails to exhibit this pattern is Spain, where sales increase significantly in January in addition to increasing in December and then fall dramatically (by over 50\%) in February. ${ }^{15}$ The other consistent features of the seasonal patterns in sales are a February decrease, a March increase (which may be due to Easter), a June or July decrease, and an October increase. These features are not as consistent across countries as the December increase and January decrease, but they still characterize a large portion of world retail sales.

It is particularly noteworthy that the two Southern Hemisphere countries, Australia and New Zealand, both exhibit seasonal patterns that are strikingly similar to those in most countries in the Northern Hemisphere. Sales in both Australia and New Zealand increase significantly in December, fall significantly in January, increase in March, decrease in June, and increase in October, thus exhibiting all of the major features of the patterns in Northern Hemisphere countries. The fact that the patterns of retail sales are so similar in Northern and Southern Hemispheres, particularly with respect to the December to January behavior, clearly suggests that demand shifts, especially Christmas, are a key determinant of the seasonal behavior of the world economy. Of course, the December increase and January decrease in retail sales also occur in Japan, so it is not entirely accurate to call this a "Christmas" effect.

The results for industrial production are presented in Table 3. The first interesting characteristic of the seasonal patterns is that in almost all countries there is a large decrease in production in either July or August, and in many countries this decrease is followed by a large increase of

sectional regressions reported in Section 4 (inclusion of these countries, however, has minimal effects on the results).

15 The celebration of Christmas on Twelfth Night (January 6th) is quite common in Spain. 
approximately the same magnitude the following month. The exact timing of this slowdown in production varies from country to country, and it is entirely absent in Australia. Several countries exhibit this behavior in July (United States, Belgium, Finland, Norway, Sweden), while others display it in August (France, Italy, Spain). In many cases the slowdown appears to be strongly concentrated in one month, rather than being spread out over several months. ${ }^{16}$ The fact that this slowdown occurs in the summer in all Northern Hemisphere countries but is absent in Australia suggests that people prefer vacations during summer weather. The fact that the slowdown is so strongly concentrated in one month may suggest that it is desirable for all activity to slow down at the same time. I discuss this possibility further below.

A second general feature of the seasonal patterns in industrial production is a winter slowdown, with production falling in most countries in December as well as in January and then recovering in February. It is noteworthy that the country with the most dramatic December through January slowdown is Australia, even though retail sales are very strong in December. The pronounced January decline in production in Australia presumably reflects the coincidence of the end of the Christmas season and the (Southern Hemisphere) summer vacation period.

Table 4 shows the seasonal dummy patterns in the money stock (M1). The most dramatic aspects of the seasonal patterns - large, positive growth rates in December and large, negative growth rates in January - are strongly consistent across countries. In addition, a high fraction of countries exhibit negative growth rates in February and positive growth rates in April. ${ }^{17}$ Comparing the results in Table 4 with those in Table 1 suggests that there is high comovement of nominal money and real output at seasonal frequencies. In addition, comparison of Table 4 with Tables 2 and 3 implies that retail sales, rather than industrial production, is the main determinant of money demand. I address these issues more directly below.

16 Integration of the seasonals in the log growth rates confirms that the level of production is dramatically lower in July or August than it is in adjacent months in many of the countries considered above (Belgium, Finland, France, Ireland, Italy, Luxembourg, Norway, Portugal, Spain, Sweden ).

17 Data on M2 for Sweden exhibit seasonal patterns similar to those in M1 for other countries. 
In Tables 5, 6 and 7 I present the seasonal patterns in the price level and nominal and real interest rates. There are not any strong, consistent patterns in the timing of the seasonal fluctuations, consistent with the fact that dummies explain an insignificant fraction of the total variation in these variables. The only countries that display (relatively) large seasonal movements in prices are Greece, Turkey, and Yugoslavia. These are the three countries (of the countries included in Table 5) that have the highest share of agriculture in GDP.

The seasonal patterns in employment and hours are displayed in Tables 8 and 9 . The employment numbers are for the economy as a whole ${ }^{18}$ while the hours numbers are for manufacturing. ${ }^{19}$ Employment always fall from the fourth quarter to the first quarter and always rises from the first quarter to the second quarter. In general, employment improves still further in the third quarter and then declines (in a number of cases only mildly) going into the fourth quarter. Hours in manufacturing always fall significantly from the fourth quarter to the first quarter and almost always increase from the third quarter to the fourth quarter. The seasonal drops in employment during the fourth quarter appear somewhat anomalous given the large increases in output that occur in the fourth quarter. One possible explanation is that there are large withdrawals from the labor force by teenagers or other low productivity workers (e.g. farm hands). In addition, the results on hours suggest that those workers who remain employed increase their work effort in the fourth quarter. I return to this issue in more detail below.

\subsection{The Relations Between Variables at Seasonal Frequencies}

The discussion to this point shows that the patterns of seasonal variation in aggregate variables

18 The employment numbers are for the establishment measure of employment, except for Australia, where they are for the household measure. For those countries for which both household and establishment data are available the seasonal patterns are quite similar.

19 In calculating hours numbers, I use industry employment and industry hours (where industry is defined as manufacturing plus mining, utilities, and construction) for Austria, manufacturing employment and mining plus manufacturing hours for Germany, manufacturing employment and mining plus manufacturing hours for males for Norway, and industry employment and mining and manufacturing hours for Sweden. In most cases the results are for quarterly numbers or quarterly averages of monthly numbers. For Greece, however, I use second month of quarter data on both employment and hours. 
are similar across countries. The points to be made in this sub-section are that the cross correlations between variables are also similar across countries and that the cross correlation properties displayed at seasonal frequencies are similar to those displayed at business cycle frequencies. That is, for the countries examined below, the key cross correlation properties ("stylized facts") that characterize business cycle fluctuations also characterize seasonal fluctuations. ${ }^{20}$

The most fundamental cross correlation property of the business cycle is that fluctuations in output across different sectors are highly positively correlated. The results presented in Table 1 on real GDP and in Table 3 on industrial production show that there is a significant aggregate cycle at seasonal frequencies as well as at business cycle frequencies. Most strikingly, there is a pronounced decline in virtually all components of output, in all countries, from the fourth quarter to the first quarter and a deep decline in manufacturing production during the third quarter.

One possible explanation for the large seasonal shifts in economic activity is that there are large seasonal shifts in preferences or technology. Rather than relying solely on large shifts in technology or preferences, however, it may be more accurate to explain the magnitude of the seasonals as the result of relatively small seasonal shifts in preferences or technology combined with increasing returns or other synergies. The feature of the seasonal patterns that is most likely an example of such synergies is the large slowdown in industrial production in either July or August in almost all countries. While the weather is certainly more conducive to summer vacations in July and/or August than in other months, it is not obvious that, for example, August is so much superior to July in France that vacations should be concentrated in August simply because of this effect. It may be that August is somewhat preferable to July, inducing many firms to shut down in this month, and other firms follow suit simply because it is desirable to shut down when ones' suppliers and/or customers are on vacation.

A second key stylized fact characterizing the business cycle is that nominal money and real

20 For discussion of the stylized facts about business cycles in the United States and other countries, see Mitchell (1927), Burns and Mitchell (1946), Friedman and Schwartz (1963,1982), Moore (1980), and Zarnowitz (1985). 
activity are highly positively correlated. ${ }^{21}$ The evidence in the literature on nominal money and real output at business cycle frequencies (see Barro (1987) for a useful summary) is based on a number of kinds of evidence, including both detailed analyses of specific "exogenous" changes in the money stock (Friedman and Schwartz (1963)) and time series analyses that allow for long lags in the relation between money and output or that account for the distinction between anticipated and unanticipated money. The approach taken here simply indicates whether there is an association between money and output at seasonal frequencies that is qualitatively similar to the joint behavior of these two variables at business cycle frequencies. I estimate an IV regression of nominal money on real output, with seasonal dummies as the only instruments. ${ }^{22}$

Table 10 presents estimates of this relation using quarterly data on real GDP as the measure of output. The coefficient estimates show a consistently strong, positive relation between the growth rate of nominal money and the growth rate of real GDP. In a typical case the estimated coefficient is between 0.4 and 0.6 , so a one percentage point increase in the rate of growth of real output is associated with approximately half a percentage point increase in the rate of growth of nominal money. Table 11 presents results using monthly seasonal components for money and industrial production. In contrast to the results for GDP, there is not a strong association between money and industrial production at seasonal frequencies. ${ }^{23}$ This is one case in which the stylized facts about seasonal cycles are not even qualitatively similar to those about business cycle. There is a long literature (e.g., Sims (1972), Litterman and Weiss (1985), Eichenbaum and Singleton (1987), Stock and Watson (1987), Christiano and Ljungqvist (1988)) examining the connection between monthly,

21 For evidence for the United States, see especially Friedman and Schwartz (1963). For evidence for other countries, see Friedman and Schwartz (1982) (United Kingdom), Meiselman (1970), ed., (a cross-section of forty-seven countries during the post-World War II period (Morris Perlman), Canada, 1867-1965 (George Macesich), Chile, 1879-1955 (John Deaver), South Korea, 1953-1961 and Brazil, 1948-1965 (Colin Campbell), Argentina, 1935-1962 (Adolfo Cesar Diz), and Japan after World War II (Michael Keran)); Meltzer (1959) (France); Courchene (1969) and Hay (1967) (Canada); and Jonung (1975) (Sweden).

22 The error term in this equation is not necessarily white noise, so I have estimated the standard errors reported in Tables 10-12 using the Hansen and Hodrick (1980)/Newey and West (1987) procedure. The damp factor was set to one, and the lag length was set equal to 4 for quarterly data and 12 for monthly data.

23 There is a somewhat stronger association between the seasonal in money and the seasonal in industrial production lagged one month. 
seasonally adjusted money and industrial production, with results that are generally although not uniformly positive.

The difference between the results using GDP and those using industrial production suggests that the relation between money and consumption may be stronger at seasonal frequencies than the relation between money and output. Table 12 presents result analogous to those in Table 11 but for retail sales rather than industrial production. The monthly seasonal pattern in retail sales shows a strong association with the seasonal in money, in contrast to the seasonal pattern in industrial production. ${ }^{24}$ The difference between the results in Tables 11 and 12 provides an additional way in which the seasonal cycle resembles the business cycle; as Mankiw and Summers (1986) have documented using seasonally adjusted data for the United States, consumption is more highly correlated with money than is income at business cycle frequencies. ${ }^{25}$

The next stylized fact that I consider is the procyclical behavior of labor productivity. Under constant returns and competition, the elasticity of output with respect to measured labor input is equal to labor's share in total output (approximately .75 in United States data). Existing estimates of this elasticity, however, always exceed labor's share and typically exceed unity. For example, Prescott (1986) estimates the elasticity to be 1.1 for the United States, while Summers and Wadhwani (1987) estimate it to be between 1.0 and 2.0 for most OECD countries.

Table 13 address the cyclicality of labor productivity at seasonal frequencies by reporting estimates of the elasticity of output with respect to labor input. The table shows the estimated coefficient on hours from IV regressions of industrial production on total hours worked in manufac-

\footnotetext{
24 Quarterly results for consumption are quite similar to those for GDP; see Appendix Table B6.

25 Faig (1987) uses the seasonal fluctuations in money, consumption, and income to estimate the transactions elasticity of the demand for money. He reports estimates of about .3, which is substantially lower than previous estimates.
} 
turing, where seasonal dummies are used as the only instruments. ${ }^{26,27,28}$ The coefficients relating industrial production to total hours indicate strong procyclicality of labor productivity at seasonal frequencies for most countries. The result for Canada is the main exception to this general conclusion. In the monthly data that are available for Canada, however, the estimated coefficient is 1.70 (.17), again implying strongly procyclical productivity.

In evaluating the implications of the coefficients in Table 13 it is useful to keep in mind the results presented in Table 3 on industrial production. Those results show that there are enormous slowdowns in economic activity in either July or August, which coincides with the summer vacation period in Northern Hemisphere countries. This suggests that the failure of labor input to move sufficiently with output at least in part reflects the presence of vacations. In the third quarter many workers on paid vacations are counted as employed, and the hours for which firms pay are counted as hours worked. In comparing the third quarter and the fourth quarter, therefore, measured labor input does not change very much but the amount of labor actually used in productive activity does, so output moves more than measured labor input.

This description of the behavior of output and labor input over the seasons does not particularly undermine the view that procyclical productivity at the seasonal frequencies reflects labor hoarding. Most of the costs associated with adjusting labor input (hiring and firing costs, training costs) are likely to be associated mainly with newly hired or permanently fired employees. While allowing workers to take vacations presumably imposes some costs on firms, these are likely to be second order. Thus, by encouraging workers to take vacations during slack periods, firms can compensate

26 As with the money/output relationship, the standard errors reported in Table 13 have been corrected using the Hansen and Hodrick (1980)/Newey and West (1987) procedure.

27 The definition of hours is always the same as that used in Table 9. The industrial production series used is always Industrial Production, Manufacturing, except for Austria and Sweden, for which it is Industrial Production, Total.

28 In Appendix B I report analogous results using real GDP as the measure of output and employment as the measure of labor in put (hours data are generally not available for the economy as a whole). The coefficients relating output to employment usually indicate that the procyclicality of labor productivity is at least as strong at seasonal frequencies as it is at conventional business cycle frequencies. The coefficients are, with two exceptions, well in excess of labor's share in ou tput and indeed exceed unity. The coefficients reported in Tables B7-B8 are also usually higher than the coefficients on employment computed with annual data by Summers and Wadhwani (1987). 
workers without incurring substantial costs of adjusting labor input. Rather than paying workers to stay at the firm and not work, it may be jointly efficient for firms to "store" their hoarded labor at the beach.

The last stylized fact to discuss is the result that prices vary less than quantities. Stated differently, prices appear "sticky." I have documented above that at seasonal as well as at conventional business cycle frequencies the variation in prices is much less than that in quantities, so this stylized fact applies across frequencies as well. It also is the case, as demonstrated in Tables 6 and 7 , that both nominal and real interest rates display relatively little variation at seasonal frequencies.

\section{The Relation Between Seasonal and Cyclical Variation: Evidence}

The results in Section 3 above establish that the patterns and importance of seasonal fluctuations are similar across countries, and they show that in almost all countries the seasonal fluctuations display cross correlation properties that are similar to those displayed by business cycle fluctuations. This section of the paper establishes that the amount of seasonal variation and the amount of cyclical variation are strongly correlated across countries.

To address this issue I consider the cross sectional relation between the standard deviation of the seasonal component and the standard deviation of the non-seasonal component of the six monthly series presented in Tables 2-7. Figures 1-6 present scatter plots of the non-seasonal standard deviation versus the seasonal standard deviation in industrial production, real retail sales, the nominal money stock, the price level, and the nominal and real interest rate. ${ }^{29}$ Table 14 reports regressions of the standard deviation of the non-seasonal component on the standard deviation of the seasonal component for the same six variables..$^{30}$ The regressions have been estimated with a

29 As in Section 3, the results for industrial production are for Total Industrial Production rather than Manufacturing Industrial Production. I have also computed all of the regressions reported in this section with Manufacturing Industrial Production, with results that are virtually identical to those presented in the text.

30 If the model specified in (1) is correct, then the estimates of the seasonal and non-seasonal standard deviations are asymptotically uncorrelated. In finite sample, there should be a negative correlation between the estimates because any variation in a series that is "mistakenly" attributed to one component must necessarily be omitted from the other component. 
heteroskedasticity correction equal to the square root of the number of monthly observations in the regression used to estimate the seasonal dummies and residuals. ${ }^{31}$

The results show that there is a strong correlation between the amount of business cycle variation displayed by a particular country and the amount of seasonal variation displayed by that country. The sign of the correlation is positive for all variables other than the real interest rate. In four of the six cases the coefficient on the seasonal standard deviation is statistically significant at the $1 \%$ level, and in a fifth case the coefficient is significant at almost the $5 \%$ level. The strongest correlation appears in the case of prices and the weakest in the case of real interest rates.

There are two kinds of models that might generate the correlation between seasonal and cyclical fluctuations demonstrated in Table 14 and Figures 1-6. The first is the kind in which some third factor is an important determinant of both the amount of cyclical variation and the amount of seasonal variation but in which there is no other connection between seasonal and cyclical fluctuations. The second is the kind in which there is a real interaction between seasonal and cyclical fluctuations.

If the first kind of model is the reason for the correlations demonstrated in Figures 1-6 and Table 14, then that correlation should disappear once a variable measuring the relevant effect is included in the regressions reported in Table 14. In the remainder of this section I demonstrate that a number of the most obvious hypotheses to explain the correlations along these lines do not appear to be the dominant source of the result. I do this by re-estimating the regressions in Table 14 with combinations of various country characteristics included as right-hand side variables. ${ }^{32}$ There are three groups of variables included as regressors in these cross sectional regressions.

The first group of variables that I consider accounts for the possibility that the degree of

31 Unweighted regression results are similar to the weighted results. I have also considered a heterosked asticity correction based on the level of GNP of the country. There appears to be no evidence.in the data to support such a correction.

32 The sources of all of the explanatory variables are the World Bank's World Development Report, 1987 and World Tables, 1987. See Appendix A for details. I have also used the Summers and Heston (1988) estimates of real GDP to measure output; this has almost no effect on the results. 
economic diversity may be an important determinant of the amount of both cyclical and seasonal variation. For example, countries that have a large number of different industries may have small amounts of both seasonal and cyclical variation because the variation in different activities is imperfectly correlated. Likewise, countries that are large in land area may haveless of both seasonal and cyclical variation because weather effects on production activities are more diversified. I use three different variables to attempt to capture this kind of effect: the land area of the country; the size of the population; and the level of GNP.

A second group of variables attempts to measure the industrial composition of output. Consider an economy that has two sectors, one seasonal and one non-seasonal. Assume that the seasonal sector (e.g., construction) displays greater cyclical variation than the non-seasonal sector. In this setting there will be a positive correlation between the amount of seasonal variation displayed by a particular economy and the amount of non-seasonal variation displayed by that economy. If one controls for the share of output originating in the construction sector, however, one can eliminate the apparent explanatory power of the seasonal standard deviation. The variables that $I$ include to account for this type of effect are the fraction of GDP due to agriculture, manufacturing, industry, and services, respectively. ${ }^{33}$

The third group of variables is included to measure the state of economic development. I include GNP per capita as one such measure, as well as average life expectancy, the birth rate, the infant mortality rate, the population relative to the number of physicians, the average daily calorie supply, the education level, the percent of the labor force in agriculture, and the percent of the population in urban areas. Each of these variables is meant to proxy for the level of economic sophistication, which night explain the amount of both seasonal and cyclical variation because a greater degree of technological or economic advancement implies a greater ability to smooth out

33 Agriculture is defined as agriculture, hunting, fishing, and forestry. Industry is defined as manufacturing, mining, construction, and utilities. Services is defined as all activity other than agriculture and industry. The agriculture, industry and service shares therefore sum to one. 
the effects of exogenous disturbances.

Due to limitations on degrees of freedom, it is not possible to simply estimate a regression that includes all of the variables described above. Instead, I have estimated a large number of regressions, each of which has the non-seasonal standard deviation as the dependent variable and includes as regressors a constant, the seasonal standard deviation and one variable from each of the three groups of variables described above. Since the results are robust across different specifications, I do not present the details of these regressions. Table 15 presents some summary statistics. For each right hand side variable, it reports the average value of the coefficient on that variable (standard deviation of the coefficients) and the average t-statistic for that coefficient (standard deviation of the t-statistics), where the averages are taken over all regressions that include that particular variable. The table also includes the average $\bar{R}^{2}$. For the seasonal standard deviation and the $\bar{R}^{2}$, the average is taken over 108 different regressions, since there are 108 different combinations of right hand side variables that consist of one variable from each of the three groups $(108=3 \times 4 \times 9)$.

The most important result reported in Table 15 is that the correlation between the seasonal and non-seasonal standard deviation is extremely robust to the inclusion of other country characteristics. Controlling for the various effects discussed above usually reduces the magnitude of the correlation, but not to a significant degree. Comparison of Table 14 with Table 15 shows that the coefficients on the seasonal standard deviations fall only slightly. The correlations between the seasonal and non-seasonal standard deviations in industrial production, retail sales, money, the price level and the nominal interest rate are all still somewhat stronger than the correlation between the seasonal and non-seasonal standard deviations of the real interest rate. ${ }^{34}$

The signs on the country control variables are often in accord with the a priori discussion above. The economic diversity variables almost always enter negatively, consistent with the no-

\footnotetext{
34 A few of the observations plotted in Figures 1-6 appear to be outliers that may be important in driving the results reported in Table 15. In fact, exclusion of the obvious outliers strengthens the results reported above for some of the variables (especially industrial production) and weakens them only slightly for the others.
} 
tion that greater diversity leads to less variability. A higher share of agriculture leads to greater volatility, which is plausible since agriculture is a relatively volatile sector. An increased share of manufacturing leads to lower volatility, which seems counterintuitive. Turning to the measures of economic development, per capita GNP almost always enters with a negative sign, suggesting that greater development leads to lower volatility. Of the other measures of the level of economic development, higher infant mortality and higher birth rates are associated with greater volatility, while higher life expectancy is associated with lower volatility.

\section{The Relation Between Seasonal and Cyclical Variation: Theory}

The results presented above indicate that there is a high degree of similarity between all types of short term aggregate fluctuations and that the amount of variation at business cycle frequencies tends to be strongly correlated cross sectionally with the amount of variation at seasonal frequencies. In this section of the paper I present a model that is consistent with the facts presented above. The model suggests that the cross sectional correlation between the amounts of seasonal and cyclical variation is the result of having the same mechanism operative across frequencies.

Consider the following simple model:

$$
\begin{gathered}
q_{t}^{i}=\beta^{i} p_{t}^{i} \\
q_{t}^{i}=s_{t}^{i}-\delta^{i} p_{t}^{i}+\epsilon_{t}^{i}
\end{gathered}
$$

where $q_{t}^{i}$ is a "quantity" variable, $p_{t}^{i}$ is the "price" of that quantity variable, $s_{t}^{i}$ is a vector of seasonal dummies, $\epsilon_{t}^{i}$ is a random shock, and $\beta^{i}$ and $\delta^{i}$ are coefficients. The superscript $i$ refers to country, and the equations are assumed to describe the determination of $q_{t}^{i}$ and $p_{t}^{i}$ in country $i$. There are numerous possible interpretations of the variables, but for convenience I refer to them as quantity and price and interpret the equations as supply and demand..$^{35}$ The only critical point is that this

35 The analysis presented in this section can be thought of, for example, as applying to the IS-LM model, with the shift variables in the second equation representing shifts of the money stock. 
model determines $q_{t}^{i}$ on a period by period basis, so there is no distinction between responses over different frequencies. In particular, the elasticity of supply with respect to price is independent of the kind of demand shift that produces the change in price.

The reduced form for $q_{t}^{i}$ is

$$
q_{t}^{i}=\left(\frac{\beta^{i}}{\beta^{i}+\delta^{i}}\right) s_{t}^{i}+\left(\frac{\beta^{i}}{\beta^{i}+\delta^{i}}\right) \epsilon_{t}^{i}
$$

and the standard deviations of the seasonal and non-seasonal components of $q_{t}^{i}$ are

$$
\begin{aligned}
& \Sigma_{s}^{i}=\theta^{i} \sigma_{s}^{i} \\
& \Sigma_{n}^{i}=\theta^{i} \sigma_{e}^{i}
\end{aligned}
$$

where $\theta^{i}=\beta^{i} /\left(\beta^{i}+\delta^{i}\right)$. The regression coefficient from OLS estimation of $\Sigma_{n}^{i}$ on $\Sigma_{s}^{i}$ is then

$$
\gamma=\frac{\operatorname{Cov}\left(\theta^{i} \sigma_{e}^{i}, \theta^{i} \sigma_{s}^{i}\right)}{\operatorname{Var}\left(\theta^{i} \sigma_{s}^{i}\right)}
$$

where the variances and covariances are calculated across countries. This can be written approximately as

$$
\gamma \approx \frac{\sigma_{e}^{i} \sigma_{s}^{i} \operatorname{Var}\left(\theta^{i}\right)+\theta^{i} \sigma_{e}^{i} \operatorname{Cov}\left(\theta^{i}, \sigma_{s}^{i}\right)+\theta^{i} \sigma_{s}^{i} \operatorname{Cov}\left(\theta^{i}, \sigma_{e}^{i}\right)+\theta^{i^{2}} \operatorname{Cov}\left(\sigma_{e}^{i}, \sigma_{s}^{i}\right)}{\sigma_{s}^{i^{2}} \operatorname{Var}\left(\theta^{i}\right)+2 \theta^{i} \sigma_{s}^{i} \operatorname{Cov}\left(\theta^{i}, \sigma_{s}^{i}\right)+\theta^{i^{2}} \operatorname{Var}\left(\sigma_{s}^{i}\right)}
$$

The expression is evaluated at the means (across countries) of the variables $\sigma_{e}^{i}, \sigma_{s}^{i}$, and $\theta^{i}$.

This formula allows us to see several things. First, there will be a cross sectional correlation between the amounts of seasonal and non-seasonal variation in $q_{t}$ even if the amounts of seasonal and non-seasonal variation in the shifts of demand are uncorrelated ( $\gamma$ is generally non-zero even if $\left.\operatorname{Cov}\left(\sigma_{e}^{i}, \sigma_{s}^{i}\right)=0\right)$. Second, there will be a cross sectional correlation between the amounts of seasonal and non-seasonal variation even if there is no correlation between the distribution of shocks and the structural parameters ( $\gamma$ is generally non-zero even if $\operatorname{Cov}\left(\theta^{i}, \sigma_{s}^{i}\right)=0$ and $\left.\operatorname{Cov}\left(\theta^{i}, \sigma_{e}^{i}\right)=0\right)$. All that is required to generate a non-zero value for $\gamma$ is that the parameters of supply and demand 
vary over countries. The crucial assumption driving the result is that the elasticities of demand and supply are the same with respect to both seasonal and non-seasonal shifts in demand and supply. The natural interpretation of the facts presented in Section 4 documenting the cross sectional correlation between seasonal and cyclical variation is therefore that the correlation results from having the same mechanism operative across frequencies in producing aggregate fluctuations.

\section{Conclusion}

As discussed in Barsky and Miron (1988), the similarity of the seasonal cycle and the business cycle suggests a number of important conclusions about competing explanations of economic fluctuations. The high correlation of nominal money and real output at seasonal frequencies provides an important example of endogenous money, and the similarity of this correlation at cyclical and seasonal frequencies casts doubt on the view that the correlation between money and output at business cycle frequencies reflects informational confusion. The high coincidence of production and sales at seasonal frequencies is problematic for production smoothing models because the anticipated and transitory seasonal fluctuations in demand are exactly the ones that firms should smooth most easily by means of inventory accumulations. The fact that there is a large expansion in output in the demand-driven fourth quarter without much increase in hours of work suggests that labor hoarding in the presence of demand fluctuations is an important source of procyclical productivity. Finally, the general similarity of the seasonal cycle and the business cycle suggests that the key stylized facts of the conventional business cycle may have little to do with the distinction between anticipated and unanticipated "shocks."

The conclusions described above rely on the identifying assumption that particular seasonal movements in the data are determined by identifiable factors such as Christmas or the weather and on the identifying assumption that the same mechanism is operative across seasonal and business cycle frequencies in producing the key cross correlation properties in the data. The results in this 
paper address both of these identifying assumptions. By comparing the patterns of seasonal fluctuations across countries and hemispheres, the paper pins down the reasons for particular seasonal movements in the data. By documenting the cross sectional correlation between the amount of seasonal and cyclical variation, the paper provides evidence that the same mechanism is operative across seasonal and business cycle frequencies in producing the key stylized facts.

There are therefore two key messages in the paper. The results demonstrate first of all that the stylized facts documented in Barsky and Miron (1988) for the United States apply across a broad range of countries. More importantly, the results provide substantial support for the conclusions from Barsky and Miron summarized above by confirming the validity of the identifying assumptions underlying that analysis. 


\section{References}

Backus, David K. and Patrick J. Kehoe (1988), "International Evidence on the Historical Properties of Business Cycles," manuscript, University of Minnesota.

Barro, Robert J. (1987), Macroeconomics, New York: Wiley and Sons.

Barsky, Robert B. and Jeffrey A. Miron (1988), "The Seasonal Cycle and the Business Cycle," Journal of Political Economy, forthcoming.

Baxter, Marianne and Alan C. Stockman (1988), "Business Cycles and the Exchange Rate System: Some International Evidence," Working Paper \# 140, Rochester Center for Economic Research, University of Rochester.

Burns, Arthur F. and Wesley C. Mitchell (1946), Measuring Business Cycles, New York: National Bureau of Economic Research.

Campbell, John and Gregory Mankiw (1986), "Are Output Fluctuations Transitory?," Quarterly Journal of Economics, CII, 4(Nov.), 857-80.

Christiano, Lawrence J. and Lars Ljungqvist (1988), "Money Does Granger-Cause Output in the Bivariate Money-Output Relation," Journal of Monetary Economics, 22, 2(Sept.), 217-36.

Clark, Truman (1984), "Interest Rate Seasonals and the Federal Reserve," Journal of Political Economy, 94, 1(Feb.), 76-125.

Courchene, T.J. (1969), “An Analysis of the Canadian Money Supply," Journal of Political Economy, 77, 3(May/June), 363-91.

Eichenbaum, Martin and Kenneth J. Singleton (1986), "Do Equilibrium Business Cycle Theories Explain Postwar U.S. Business Cycles?," NBER Macro Annual, 91-134.

Faig, Miquel (1987), "Seasonal Fluctuations and the Transactions Elasticity of the Aggregate Demand for Money," Working Paper \# 8721, Institute for Policy Analysis, Department of Economics, University of Toronto.

Friedman, Milton and Anna J. Schwartz (1963), A Monetary History of the United States, 186\%1960, Princeton: Princeton University Press.

NBER.

(1982), Monetary Trends in the United States and the United Kingdom, New York:

Fuller, Wayne A. (1976), Introduction to Statistical Time Series, New York: Wiley.

Gerlach, Stefan (1988), "World Business Cycles under Fixed and Flexible Exchange Rates," Journal of Money, Credit and Banking, 20, 4(Nov.), 621-32.

Hansen, Lars P. and Robert J. Hodrick (1980), "Forward Rates as Optimal Predictors of Future Spot Rates: An Econometric Analysis," Journal of Political Economy, 88, 5(Oct.), 829-53.

Hay, K.A.J. (1967), "Money and Cycles in Post Confederation Canada," Journal of Political Economy, 75, 3(June), 262-73.

Hodrick, Robert J. and Edward C. Prescott (1980), "Post-War U.S. Business Cycles: An Empirical Investigation," WP, Carnegie-Mellon University.

Jonung, Lars (1975), "Money and Prices in Sweden, 1732-1972," in Inflation and the World Economy, J.M. Parkin and G. Zis, eds., Manchester: Manchester University Press. 
Kemmerer, Edwin W. (1910), Seasonal Variations in the Relative Demand for Money and Capital in the United States, National Monetary Commission, S.Doc. \#588, 61st Cong., 2d. session.

Litterman, Robert and Laurence Weiss (1985), "Money, Real Interest Rates, and Output: A Reinterpretation of Postwar U.S. Data," Econometrica, 53, 129-56.

Lucas, Robert E., Jr. (1977), "Understanding Business Cycles," Carnegie-Rochester Conference Series, vol. 5.

Macaulay, Frederick R. (1938), Some Theoretical Problems Suggested by Movements of Interest Rates, Bond Yields and Stock Prices in the United States Since 1856, New York: NBER.

Mankiw, N. Gregory and Lawrence H. Summers (1986), "Money Demand and the Effects of Fiscal Policies," Journal of Money, Credit and Banking, 18, 4(Nov.), 415-29.

Meiselman, David (1970), Varieties of Monetary Experience, ed., Chicago: Chicago University Press.

Meltzer, Allan H. (1959), "The Behavior of the French Money Supply: 1938-54," Journal of Political Economy, 67, 3(June), 275-91.

Mitchell, Wesley C. (1927) The Business Cycle: The Problem and Its Setting, New York: NBER.

Moore, Geoffrey (1980), International Comparisons of Business Cycles, New York: NBER.

Morgenstern, Oskar (1959), International Financial Transactions and Business Cycles, Princeton: Princeton University Press.

Nelson, Charles R. and Charles I. Plosser (1982), "Trends and Random Walks in Macroeconomic Times Series: Some Evidence and Implications," Journal of Monetary Economics, 10, 139-62.

Newey, Whitney and Kenneth West (1987), "A Simple, Positive Definite, Heteroskedasticity and Autocorrelation Consistent Covariance Matrix," Econometrica, 55, 703-8.

Pierce, David A. (1978), "Seasonal Adjustment When Both Deterministic and Stochastic Seasonality are Present," in Arnold Zellner, ed., Seasonal Adjustment of Economic Time Series, Washington: Bureau of the Census.

Prescott, Edward C. (1986), "Theory Ahead of Business Cycle Measurement," Carnegie-Rochester Conference Series, vol. 25.

Sims, Christopher (1972), "Money, Income, and Causality," American Economic Review, LXII, 4, 540-552.

Stock, James and Mark Watson (1987), "Interpreting the Money - Income Correlation," NBER WP \# 2228.

Summers, Robert and Alan Heston (1988), "A New Set of International Comparisons of Real Product and Prices for 130 Countries," Review of Income and Wealth, 34, 1(Mar.).

Summers, Lawrence H. and Sushil B. Wadhwani (1987), "Some International Evidence on Labor Cost Flexibility and Output Variability," Discussion Paper \# 1353, Harvard Institute for Economic Research.

Zarnowitz, Victor (1985), "Recent Work on Business Cycles in Historical Perspectives," Journal of Economic Literature, XXIII, 2(June), 523-80. 


\section{APPENDIX A: SOURCES OF THE DATA}

1. All time series data on aggregate variables are from the DRI databases Current Economic Indicators, OECD Main Economic Indicators, Japan, or US Central.

2. In most cases the national accounts data are the real, seasonally unadjusted data series reported directly by DRI. For five countries (Australia, Finland, Netherlands, Norway, and the United States), I have constructed the real, unadjusted data by dividing nominal unadjusted data by the seasonally unadjusted CPI. For a number of countries there are data available on both real, unadjusted and nominal unadjusted NIA data. For these countries I have computed results using both measures and verified that the results are not sensitive to the distinction. In virtually all cases the seasonal movements in the alternative series are almost identical.

3. The nominal interest rate is the three month T-bill rate except for France (one month loan rate secured against interbank money), Germany (two to three month $\mathrm{T}$-bill rate), and Japan (two month T-bill rate). For Sweden, the nominal interest rate data are missing for 1981:4.

4. All of the explanatory variables used in the cross-sectional regressions are from the World Bank's World Development Report, 1987 and World Tables, 1987. There are missing values for a few of the right hand side variables for a small number of countries; details are available on request.

\section{Explanatory Variables Used in Cross Sectional Regressions}

I.1 Total population, in billions, mid-1985.

I.2 Area, millions of square kilometers.

I.3 Total GNP in billions of 1985 dollars.

II.1 Share of agriculture in GDP, 1985

II.2 Share of manufacturing in GDP, 1985

II.3 Share of industry in GDP, 1985

II.4 Share of services in GDP, 1985

III.1 GNP per capita in thousands of 1985 dollars.

III. 2 Life expectancy at birth as of 1985

III.3 Crude birth rate per thousand population, 1985

III.4 Infant mortality rate, 1985

III.5 Population per physician, thousands, 1981

III.6 Daily calorie supply per capita, thousands, 1985

III.7 Number of people enrolled in school, as a percent of age group, higher education, 1984

III.8 Percent of labor force in Agriculture, 1980

III.9 Percent of pupulation in urban areas, 1985 


\begin{tabular}{|l|c|c|r|r|r|r|r|r|}
\hline \multicolumn{7}{|c|}{ Table 1: Real Gross Domestic Product, Log Growth Rates (Quarterly) } \\
\hline & Sample Period & Std. Dev. of Seasonals & Std. Dev. of Residuals & $R^{2}$ & \multicolumn{1}{|c|}{ Q1 } & \multicolumn{1}{c|}{ Q2 } & \multicolumn{1}{|c|}{ Q3 } & \multicolumn{1}{|c|}{ Q4 } \\
\hline Argentina & $1977: 2-1987: 2$ & 3.87 & 3.53 & .546 & -6.09 & 2.53 & -.39 & 3.95 \\
Australia & $1960: 2-1987: 3$ & 9.02 & 2.31 & .938 & -14.37 & .09 & 4.05 & 10.23 \\
Austria & $1973: 2-1987: 3$ & 9.07 & 1.12 & .985 & -15.60 & 6.52 & 5.66 & 3.42 \\
Canada & $1961: 2-1987: 3$ & 6.17 & 2.07 & .899 & -6.76 & 4.59 & 7.49 & -5.32 \\
Finland & $1970: 2-1987: 2$ & 7.40 & 2.95 & .863 & -12.38 & 4.50 & 1.39 & 6.49 \\
Germany & $1960: 2-1987: 3$ & 4.75 & 2.51 & .782 & -7.61 & 3.24 & 4.64 & -.27 \\
Italy & $1970: 2-1984: 4$ & 5.68 & 1.62 & .924 & -9.57 & 4.72 & .78 & 4.07 \\
Japan & $1965: 2-1987: 1$ & 10.83 & 2.19 & .961 & -17.22 & .05 & 5.40 & 11.77 \\
Netherlands & $1977: 2-1987: 4$ & 5.39 & 2.52 & .821 & -4.04 & 6.41 & -6.31 & 3.93 \\
Norway & $1978: 2-1987: 4$ & 3.28 & 1.93 & .742 & -4.17 & -2.18 & 2.78 & 3.57 \\
Sweden & $1970: 2-1987: 3$ & 11.56 & 1.87 & .974 & -9.38 & .42 & -9.81 & 18.76 \\
Taiwan & $1961: 2-1987: 3$ & 3.56 & 3.44 & .517 & -3.54 & 1.02 & -2.87 & 5.39 \\
United King. & $1955: 2-1987: 3$ & 3.46 & 2.15 & .721 & -5.90 & 1.65 & 1.22 & 3.03 \\
United States & $1948: 2-1985: 4$ & 5.13 & 1.84 & .886 & -8.17 & 3.96 & -.56 & 4.77 \\
\hline
\end{tabular}




\begin{tabular}{|c|c|c|c|c|c|c|c|c|c|c|c|c|}
\hline & \multicolumn{3}{|c|}{ Sample Period } & \multicolumn{3}{|c|}{ Std. Dev. of Seasonals } & \multicolumn{3}{|c|}{ Std. Dev. of Residuals } & \multicolumn{3}{|c|}{$R^{2}$} \\
\hline Australia & \multicolumn{3}{|c|}{$1961: 5-1987: 11$} & \multicolumn{3}{|c|}{12.73} & \multicolumn{3}{|c|}{3.17} & \multicolumn{3}{|c|}{.942} \\
\hline Austria & \multicolumn{3}{|c|}{$1960: 2-1987: 10$} & \multicolumn{3}{|c|}{17.80} & \multicolumn{3}{|c|}{5.53} & \multicolumn{3}{|c|}{.912} \\
\hline Belgium & \multicolumn{3}{|c|}{ 1969:2-1987:9 } & \multicolumn{3}{|c|}{11.92} & \multicolumn{3}{|c|}{3.73} & \multicolumn{3}{|c|}{.911} \\
\hline Canada & \multicolumn{3}{|c|}{$1960: 2-1987: 11$} & \multicolumn{3}{|c|}{12.72} & \multicolumn{3}{|c|}{4.00} & \multicolumn{3}{|c|}{.910} \\
\hline Denmark & \multicolumn{3}{|c|}{ 1960:2-1987:11 } & \multicolumn{3}{|c|}{12.83} & & 5.57 & & & .841 & \\
\hline Finland & & $0: 2-198^{\prime}$ & & & 15.7 & & & 6.21 & & & .865 & \\
\hline France & & $0: 2-198$ & & & 20.3 & & & 6.32 & & & .912 & \\
\hline Germany & & $0: 2-198$ & & & 15.0 & & & 4.60 & & & .914 & \\
\hline Greece & & $4: 7-1987$ & & & 10.6 & & & 5.29 & & & .801 & \\
\hline Italy & & $0: 2-1987$ & & & 19.2 & & & 5.52 & & & .924 & \\
\hline Japan & & $0: 2-1986$ & & & 16.5 & & & 2.93 & & & .969 & \\
\hline Netherlands & & $0: 2-1987$ & & & 8.7 & & & 5.89 & & & .689 & \\
\hline Norway & & $0: 2-198$ & & & 15.5 & & & 4.94 & & & .908 & \\
\hline New Zealand & & $0: 2-198$ & & & 11.3 & & & 6.57 & & & .748 & \\
\hline Spain & & $5: 2-1987$ & & & 23.2 & & & 8.35 & & & .885 & \\
\hline Sweden & & $3: 2-198$ & & & 14.1 & & & 4.50 & & & .909 & \\
\hline Switzerland & & $0: 2-1987$ & & & 13.9 & & & 5.14 & & & .881 & \\
\hline United King. & & $0: 2-198$ & & & 11.4 & & & 2.25 & & & .963 & \\
\hline United States & & $0: 2-1987$ & & & 11.0 & & & 2.83 & & & .938 & \\
\hline Yugoslavia & & $0: 2-198$ & & & 14.2 & & & 10.19 & & & .662 & \\
\hline & JAN & $F E B$ & $M A R$ & $A P R$ & $M A Y$ & JUN & JUL & $A U G$ & $S E P$ & $O C T$ & NOV & $D E C$ \\
\hline Australia & -33.77 & -5.70 & 7.15 & -.41 & 6.63 & -7.80 & 2.27 & .66 & -1.03 & 4.40 & 2.82 & 24.77 \\
\hline Austria & -52.38 & -2.66 & 13.54 & .05 & -.08 & -.77 & 4.80 & -1.46 & -.47 & 6.81 & 3.08 & 29.53 \\
\hline Belgium & -27.28 & -3.88 & 14.56 & .12 & .34 & 1.46 & -11.67 & -.50 & 7.37 & 3.62 & -6.78 & 22.65 \\
\hline Canada & -36.61 & -4.27 & 14.59 & 4.66 & 6.41 & -1.71 & -4.95 & -1.99 & -.89 & 5.57 & 2.49 & 16.70 \\
\hline Denmark & -30.17 & -10.79 & 9.00 & 1.04 & 4.89 & -1.86 & 2.48 & -1.64 & -4.14 & 4.49 & -2.40 & 29.11 \\
\hline Finland & -43.50 & 1.22 & 3.54 & 11.27 & 4.97 & -2.69 & -8.85 & -.73 & 2.76 & 2.25 & .47 & 29.29 \\
\hline France & -47.02 & -18.32 & 15.94 & -2.34 & 4.00 & -.13 & -5.15 & -8.67 & 21.62 & 3.18 & -3.02 & 39.92 \\
\hline Germany & -42.20 & -3.34 & 17.26 & -.20 & -2.21 & -4.44 & 3.90 & -7.65 & 3.75 & 11.13 & 3.44 & 20.56 \\
\hline Greece & -23.18 & 2.11 & -9.24 & 12.38 & -9.35 & -2.89 & -4.28 & 4.98 & .53 & 7.28 & 1.75 & 19.91 \\
\hline Italy & -47.07 & -6.65 & 16.36 & -1.42 & .30 & -1.12 & -2.69 & -13.25 & 19.20 & 8.16 & -8.36 & 36.53 \\
\hline Japan & -43.12 & -3.42 & 17.94 & -2.89 & -2.48 & -.39 & 7.85 & -7.95 & -2.36 & 4.96 & .80 & 31.06 \\
\hline Netherlands & -16.19 & -13.87 & 15.78 & .84 & 3.79 & -4.48 & .48 & -6.50 & 4.45 & 7.74 & .01 & 7.97 \\
\hline Norway & -44.96 & -2.94 & 9.45 & 1.97 & 6.13 & 3.51 & -4.46 & .58 & -.89 & 6.33 & -1.92 & 27.21 \\
\hline New Zealand & -31.44 & .13 & 11.18 & -2.99 & 6.75 & -8.34 & 3.43 & .75 & -.71 & .63 & 2.57 & 18.02 \\
\hline Spain & 10.61 & -54.83 & .14 & 2.03 & 7.13 & 1.83 & 28.90 & -34.23 & 4.51 & 18.23 & -11.41 & 27.10 \\
\hline Sweden & -38.99 & 6.10 & 10.81 & 3.96 & 1.21 & -1.98 & -3.50 & .90 & -.11 & 8.98 & -1.99 & 26.79 \\
\hline Switzerland & -33.40 & -12.79 & 13.53 & 1.28 & -1.69 & -3.32 & -3.19 & -7.54 & 3.32 & 9.56 & 8.36 & 25.89 \\
\hline United King. & -32.78 & -3.85 & 4.07 & 1.37 & .67 & -.92 & 3.18 & -3.09 & .57 & 4.32 & 6.14 & 20.30 \\
\hline United States & -30.65 & -3.50 & 13.12 & 1.16 & 3.85 & -.58 & -2.04 & 1.08 & -4.44 & 4.42 & .27 & 17.31 \\
\hline Yugoslavia & -43.59 & 2.74 & 15.76 & 9.24 & -8.48 & 6.80 & 1.62 & 3.28 & 1.53 & .61 & .02 & 10.46 \\
\hline
\end{tabular}




\begin{tabular}{|c|c|c|c|c|c|c|c|c|c|c|c|c|}
\hline & \multirow{2}{*}{\multicolumn{3}{|c|}{ Sample Period }} & \multirow{2}{*}{\multicolumn{3}{|c|}{ Std. Dev. of Seasonals }} & \multirow{2}{*}{\multicolumn{3}{|c|}{ Std. Dev. of Residuals }} & \multirow{2}{*}{\multicolumn{3}{|c|}{$R^{2}$}} \\
\hline & & & & & & & & & & & & \\
\hline Australia & \multicolumn{3}{|c|}{ 1963:2-1987:9 } & \multicolumn{3}{|c|}{12.29} & \multicolumn{3}{|c|}{2.72} & \multicolumn{3}{|c|}{.953} \\
\hline Austria & \multicolumn{3}{|c|}{$1960: 2-1987: 11$} & \multicolumn{3}{|c|}{6.56} & \multicolumn{3}{|c|}{3.37} & \multicolumn{3}{|c|}{.791} \\
\hline Belgium & \multicolumn{3}{|c|}{$1960: 2-1987: 9$} & \multicolumn{3}{|c|}{10.49} & \multicolumn{3}{|c|}{4.55} & \multicolumn{3}{|c|}{.841} \\
\hline Canada & \multicolumn{3}{|c|}{$1960: 2-1987: 11$} & \multicolumn{3}{|c|}{5.71} & \multicolumn{3}{|c|}{2.37} & \multicolumn{3}{|c|}{.847} \\
\hline Finland & 196 & $: 2-198$ & 11 & & 16.4 & & & 5.08 & & & .913 & \\
\hline France & 196 & $: 2-198$ & 11 & & 17.4 & & & 4.47 & & & .938 & \\
\hline Germany & 196 & $: 2-198$ & 11 & & 7.0 & & & 3.56 & & & .795 & \\
\hline Greece & 196 & $2-198$ & 10 & & 4.3 & & & 4.35 & & & .503 & \\
\hline Ireland & 197 & $: 8-198$ & 10 & & 8.5 & & & 3.94 & & & .824 & \\
\hline Italy & 196 & $: 2-198$ & 10 & & 22.5 & & & 9.23 & & & .856 & \\
\hline Japan & 196 & $: 2-198$ & 11 & & 5.3 & & & 1.95 & & & .880 & \\
\hline Luxembourg & 196 & $: 2-198$ & & & 7.8 & & & 6.23 & & & .613 & \\
\hline Netherlands & 196 & $: 2-198$ & :11 & & 6.7 & & & 3.64 & & & .774 & \\
\hline Norway & 196 & $: 2-198$ & 11 & & 18.1 & & & 8.18 & & & .831 & \\
\hline Portugal & 196 & $: 2-198$ & & & 9.0 & & & 6.58 & & & .652 & \\
\hline Spain & 196 & $: 2-198$ & & & 13.9 & & & 8.38 & & & .735 & \\
\hline Sweden & 196 & $: 2-198$ & 11 & & 32.9 & & & 5.61 & & & .972 & \\
\hline United King. & 196 & $: 2-198$ & 11 & & 6.8 & & & 2.92 & & & .846 & \\
\hline United States & 196 & $: 2-198$ & :12 & & 2.4 & & & 1.17 & & & .813 & \\
\hline Yugoslavia & 196 & $: 2-198$ & 11 & & 9.0 & & & 3.37 & & & .877 & \\
\hline & $J A N$ & $F E B$ & $M A R$ & $A P R$ & $M A Y$ & JUN & $J U L$ & $A U G$ & $S E P$ & $O C T$ & NOV & $D E C$ \\
\hline Australia & -21.41 & 33.47 & -.16 & -3.00 & .19 & -.59 & 1.44 & .28 & 2.83 & -.18 & 1.64 & -14.50 \\
\hline Austria & -13.12 & 5.32 & 2.13 & 1.78 & 2.80 & .18 & -13.22 & .57 & 10.00 & 2.36 & 3.80 & -2.59 \\
\hline Belgium & -1.29 & 5.90 & .24 & 1.70 & -.65 & -.84 & -27.11 & 17.67 & 10.78 & .05 & 3.07 & -9.50 \\
\hline Canada & .07 & 6.72 & -.40 & -1.72 & -.65 & 3.38 & -13.70 & 4.36 & 7.78 & .01 & 1.79 & -7.66 \\
\hline Finland & -.03 & 1.29 & -.07 & 2.29 & -.46 & -5.61 & -41.79 & 36.99 & 6.96 & 1.68 & 1.63 & -2.89 \\
\hline France & -.51 & 1.77 & -.39 & -.55 & -2.84 & 1.68 & -12.12 & -36.54 & 45.68 & 3.76 & 1.83 & -1.76 \\
\hline Germany & -8.62 & 6.32 & 1.50 & 1.88 & -1.18 & .61 & -11.79 & -4.58 & 15.84 & 1.74 & 4.29 & -5.99 \\
\hline Greece & -7.19 & 4.93 & 2.30 & -.69 & 1.96 & 4.76 & -1.75 & -3.46 & 8.50 & -4.69 & -1.55 & -3.13 \\
\hline Ireland & -3.61 & 7.87 & 3.94 & -.49 & 1.70 & 3.44 & -9.84 & -13.96 & 18.86 & -.55 & 1.81 & -9.16 \\
\hline Italy & 1.46 & 4.37 & .66 & .25 & .49 & -.29 & -4.30 & -52.17 & 56.58 & -1.04 & 1.48 & -7.48 \\
\hline Japan & -10.88 & 5.78 & 7.93 & -5.56 & -2.21 & 3.27 & .44 & -5.91 & 5.84 & -.60 & -.67 & 2.57 \\
\hline Luxembourg & .26 & 4.98 & .45 & 2.39 & 1.91 & -.70 & -6.02 & -16.56 & 18.50 & -.53 & 1.45 & -6.12 \\
\hline Netherlands & -5.75 & 2.51 & -.64 & -.63 & -3.62 & -1.00 & -17.11 & 5.59 & 10.28 & 6.64 & 3.74 & -.01 \\
\hline Norway & 4.61 & 5.74 & -4.41 & -6.69 & -2.09 & 8.40 & -44.76 & 38.75 & 7.64 & 2.33 & 2.64 & -12.17 \\
\hline Portugal & -1.16 & 2.48 & 1.46 & .97 & -2.64 & .55 & -4.92 & -19.23 & 23.62 & 1.72 & -.34 & -2.50 \\
\hline Spain & -.43 & -.78 & 4.01 & -3.33 & 2.83 & -2.05 & -2.68 & -32.74 & 33.97 & 4.16 & -.24 & -2.72 \\
\hline Sweden & -4.38 & 1.60 & 1.17 & 5.05 & -2.38 & 1.13 & -84.48 & 75.17 & 6.65 & 2.95 & 1.34 & -3.81 \\
\hline United King. & .24 & 6.27 & 1.42 & -7.09 & .92 & .24 & -9.40 & -5.80 & 16.09 & 2.97 & 2.55 & -8.42 \\
\hline United States & .15 & 2.60 & .27 & -.39 & .11 & 2.35 & -5.19 & 3.42 & 2.36 & -.35 & -2.22 & -3.10 \\
\hline Yugoslavia & -17.29 & 4.30 & 10.82 & -3.32 & -1.22 & 2.89 & -17.07 & 9.21 & 7.30 & 4.00 & -5.71 & 6.09 \\
\hline
\end{tabular}




\begin{tabular}{|c|c|c|c|c|c|c|c|c|c|c|c|c|}
\hline \multicolumn{13}{|c|}{ Table 4: Money Stock, Log Growth Rates (Monthly) } \\
\hline & \multicolumn{3}{|c|}{ Sample Period } & \multicolumn{3}{|c|}{ Std. Dev. of Seasonals } & \multicolumn{3}{|c|}{ Std. Dev. of Residuals } & \multicolumn{3}{|c|}{$R^{2}$} \\
\hline Australia & \multirow{2}{*}{\multicolumn{3}{|c|}{ 1960:7 -1987:11 }} & \multicolumn{3}{|c|}{1.64} & \multicolumn{3}{|c|}{1.23} & \multicolumn{3}{|c|}{.638} \\
\hline Austria & \multicolumn{2}{|c|}{$1960: 2-1987: 11$} & & \multicolumn{3}{|c|}{2.16} & \multicolumn{3}{|c|}{1.94} & \multicolumn{3}{|c|}{.554} \\
\hline Belgium & \multicolumn{3}{|c|}{$1976: 1-1987: 12$} & \multicolumn{3}{|c|}{2.31} & \multicolumn{3}{|c|}{1.31} & \multicolumn{3}{|c|}{.757} \\
\hline Canada & \multicolumn{3}{|c|}{$1960: 2-1987: 12$} & & 1.9 & & & 1.5 & & & .631 & \\
\hline Denmark & 1970 & $: 3-198$ & $7: 11$ & & 4.2 & & & 2.99 & & & .671 & \\
\hline Finland & 1960 & $: 2-198$ & $7: 11$ & & 2.5 & & & 3.3 & & & .358 & \\
\hline France & 1970 & $: 1-198$ & $7: 11$ & & 2.6 & & & 1.6 & & & .731 & \\
\hline Germany & 1960 & $: 2-198$ & $7: 12$ & & 2.7 & & & 1.26 & & & .827 & \\
\hline Greece & 1960 & $: 2-198$ & $7: 10$ & & 3.7 & & & 2.9 & & & .622 & \\
\hline Iceland & 1960 & $: 2-198$ & $7: 10$ & & 2.2 & & & 4.46 & & & .195 & \\
\hline Ireland & 1976 & $: 11-198$ & $7: 12$ & & 2.9 & & & 1.8 & & & .721 & \\
\hline Italy & 1962 & $: 1-198$ & $7: 11$ & & 2.3 & & & 1.7 & & & .638 & \\
\hline Japan & 1960 & $: 2-198$ & $7: 11$ & & 3.9 & & & 1.5 & & & .859 & \\
\hline Netherlands & 1960 & $: 2-198$ & 7:10 & & 1.7 & & & $1.5 \varepsilon$ & & & .557 & \\
\hline Norway & 1966 & $: 2-198$ & $7: 10$ & & 2.2 & & & 1.96 & & & .566 & \\
\hline New Zealand & 1977 & $: 4-198$ & $7: 10$ & & 4.5 & & & $3.0 \mathrm{~s}$ & & & .680 & \\
\hline Spain & 1960 & $: 2-198$ & $7: 11$ & & 3.3 & & & 1.17 & & & .890 & \\
\hline Switzerland & 1960 & $: 2-198$ & $7: 11$ & & 1.7 & & & 1.4 & & & .604 & \\
\hline Taiwan & 1968 & $: 2-198$ & $7: 12$ & & 3.6 & & & 3.17 & & & .563 & \\
\hline Turkey & 1977 & $: 1-198$ & $7: 12$ & & 5.7 & & & $5.0^{\circ}$ & & & .562 & \\
\hline United King. & 1971 & $: 7-198$ & $7: 12$ & & 1.3 & & & 1.8 & & & .340 & \\
\hline United States & 1960 & $: 2-198$ & $7: 12$ & & $1.4^{\prime}$ & & & .61 & & & .852 & \\
\hline Yugoslavia & 1964 & $: 11-198$ & $7: 10$ & & 1.0 & & & 2.47 & & & .147 & \\
\hline & $J A N$ & $F E B$ & MAR & $A P R$ & $M A Y$ & $J U N$ & $J U L$ & $A \cup G$ & $S E P$ & $O C T$ & NOV & $D E C$ \\
\hline Australia & -.79 & -.33 & .01 & -.81 & -3.28 & -.26 & -.92 & -.47 & .58 & 1.35 & .92 & 4.01 \\
\hline Austria & -3.78 & .69 & -.41 & .97 & 1.18 & 1.80 & -.26 & .49 & 1.16 & -4.42 & 3.64 & -1.06 \\
\hline Belgium & -1.54 & -2.39 & 1.77 & 1.63 & 1.35 & 3.46 & -4.25 & -2.25 & .71 & -1.56 & -.10 & 3.18 \\
\hline Canada & -3.97 & -3.17 & .03 & 1.42 & .22 & 1.28 & 1.43 & -.47 & .30 & .15 & -.90 & 3.67 \\
\hline Denmark & -9.37 & -1.11 & 3.52 & 1.10 & -.67 & 5.64 & -6.73 & -1.38 & 3.09 & .00 & .56 & 5.35 \\
\hline Finland & -4.55 & -.97 & -.76 & .54 & 1.27 & 1.65 & -2.67 & -.45 & .48 & -1.73 & .83 & 6.37 \\
\hline France & -3.98 & -1.94 & 1.26 & .31 & -1.17 & 2.31 & .52 & -3.28 & 1.45 & .26 & -2.08 & 6.32 \\
\hline Germany & -7.51 & .05 & -.34 & .74 & 1.27 & 1.16 & -.36 & -.64 & -.42 & -.25 & 5.59 & .71 \\
\hline Greece & -8.21 & -1.38 & -1.35 & 4.17 & -2.71 & 1.97 & 1.34 & .69 & .38 & -1.22 & -1.65 & 7.97 \\
\hline Iceland & -1.80 & -.48 & 2.47 & 4.17 & 2.50 & -1.85 & .72 & -3.40 & -.57 & .83 & .22 & -2.83 \\
\hline Ireland & -5.36 & -3.51 & 2.84 & -1.92 & -.44 & 2.65 & -1.21 & .98 & 2.29 & -2.04 & .43 & 5.30 \\
\hline Italy & -4.05 & -1.79 & -.03 & -.12 & -.26 & .28 & .31 & -1.67 & .64 & .04 & -.05 & 6.68 \\
\hline Japan & -7.57 & -2.67 & 4.00 & .29 & -.99 & .84 & -1.69 & -2.25 & 1.26 & -2.01 & 1.58 & 9.22 \\
\hline Netherlands & -.41 & -.75 & .80 & 2.09 & 4.38 & -.12 & -2.00 & -2.44 & -.47 & -1.38 & .44 & -.11 \\
\hline Norway & -.48 & -2.35 & -2.25 & -.02 & -1.63 & 4.90 & -.41 & -1.70 & .89 & 2.22 & -2.13 & 2.97 \\
\hline New Zealand & -7.88 & 5.59 & -6.40 & 2.77 & -.27 & -1.31 & -1.33 & 1.93 & -5.24 & 1.87 & 2.08 & 8.19 \\
\hline Spain & -7.51 & -1.20 & .75 & -.20 & -.45 & 2.18 & 1.40 & -2.73 & 1.02 & -.75 & -.26 & 7.76 \\
\hline Switzerland & -3.44 & -1.66 & 1.16 & -.46 & -.45 & .79 & -2.13 & -.79 & 1.67 & .90 & 1.34 & 3.07 \\
\hline Taiwan & 3.43 & -6.36 & -3.53 & -.59 & .95 & 4.42 & -4.28 & .33 & -.84 & -.04 & -.57 & 7.08 \\
\hline Turkey & -13.62 & -1.89 & -1.44 & 1.11 & -.12 & -.13 & 2.38 & 1.91 & -1.78 & 1.95 & -1.81 & 13.44 \\
\hline United King. & -3.51 & -1.03 & 1.32 & 1.71 & -.07 & .10 & .88 & -.93 & -.11 & .13 & .74 & .77 \\
\hline United States & -.71 & -3.23 & .08 & 1.91 & -2.20 & 1.08 & .39 & -.79 & .49 & .46 & .69 & 1.84 \\
\hline Yugoslavia & .53 & -.99 & -.83 & .59 & -.90 & -1.00 & 2.50 & 1.05 & -1.39 & -.29 & -.25 & .08 \\
\hline
\end{tabular}




\begin{tabular}{|c|c|c|c|c|c|c|c|c|c|c|c|c|}
\hline \multicolumn{13}{|c|}{ Table 5: Consumer Price Index, Log Growth Rates (Monthly) } \\
\hline & \multicolumn{3}{|c|}{ Sample Period } & \multicolumn{3}{|c|}{ Std. Dev. of Seasonals } & \multicolumn{3}{|c|}{ Std. Dev. of Residuals } & \multicolumn{3}{|c|}{$R^{2}$} \\
\hline Austria & \multicolumn{3}{|c|}{$1960: 2-1987: 12$} & & \multicolumn{3}{|c|}{.57} & \multicolumn{3}{|c|}{.239} \\
\hline Belgium & \multicolumn{3}{|c|}{$1960: 2-1987: 12$} & \multicolumn{3}{|c|}{.10} & \multicolumn{3}{|c|}{.38} & \multicolumn{3}{|c|}{.060} \\
\hline Canada & \multicolumn{3}{|c|}{$1960: 2-1987: 12$} & \multicolumn{3}{|c|}{.12} & \multicolumn{3}{|c|}{.38} & \multicolumn{3}{|c|}{.087} \\
\hline Denmark & \multicolumn{3}{|c|}{$1967: 2-1987: 12$} & \multicolumn{3}{|c|}{.25} & \multicolumn{3}{|c|}{.66} & & .122 & \\
\hline Finland & 196 & $0: 2-19$ & 7:12 & & .2 & & & .9 & & & .052 & \\
\hline France & 196 & $0: 2-19$ & $7: 12$ & & .0 & & & .3 & & & .051 & \\
\hline Germany & 196 & $0: 2-19$ & $7: 12$ & & .2 & & & .2 & & & .345 & \\
\hline Greece & 196 & $0: 2-19$ & $7: 12$ & & .9 & & & .9 & & & .500 & \\
\hline Italy & 196 & $0: 2-19$ & $7: 11$ & & .1 & & & .5 & & & .060 & \\
\hline Japan & 196 & $0: 2-19$ & $7: 12$ & & .5 & & & .6 & & & .357 & \\
\hline Luxembourg & 196 & $0: 2-19$ & $7: 12$ & & .1 & & & .4 & & & .048 & \\
\hline Netherlands & 196 & $0: 2-19$ & $7: 12$ & & .3 & & & .6 & & & .246 & \\
\hline Norway & 196 & $0: 2-19$ & $7: 12$ & & .4 & & & .8 & & & .213 & \\
\hline Portugal & 196 & $0: 2-19$ & $7: 10$ & & .5 & & & 1.4 & & & .119 & \\
\hline Spain & 196 & $0: 2-19$ & $7: 12$ & & .2 & & & .7 & & & .078 & \\
\hline Sweden & 196 & $0: 2-19$ & $7: 12$ & & .2 & & & .9 & & & .054 & \\
\hline Switzerland & 196 & $0: 2-19$ & $7: 12$ & & .1 & & & .3 & & & .164 & \\
\hline Turkey & 196 & $9: 5-19$ & $7: 12$ & & 1.5 & & & 3.2 & & & .184 & \\
\hline United King. & 196 & $2: 2-19$ & $7: 12$ & & .3 & & & .6 & & & .246 & \\
\hline United States & 196 & $0: 2-1 \hat{9}$ & $7: 12$ & & .0 & & & .3 & & & .036 & \\
\hline Yugoslavia & 196 & $0: 2-19$ & $7: 12$ & & .8 & & & 3.1 & & & .066 & \\
\hline & $J A N$ & $F E B$ & $M A R$ & $A P R$ & $M A Y$ & JUN & $J U L$ & $A U G$ & $S E P$ & $O C T$ & NOV & $D E C$ \\
\hline Austria & .58 & -.02 & -.06 & .05 & -.07 & .72 & -.32 & -.35 & -.35 & -.12 & -.03 & -.03 \\
\hline Belgium & .21 & .07 & -.14 & .02 & -.04 & -.00 & .11 & -.15 & .06 & -.04 & -.05 & -.05 \\
\hline Canada & -.06 & -.02 & .04 & .01 & .04 & .18 & .18 & -.05 & -.30 & .00 & .04 & -.08 \\
\hline Denmark & -.29 & -.16 & .20 & .13 & .45 & -.18 & .08 & -.18 & .22 & -.01 & .20 & -.45 \\
\hline Finland & .50 & .04 & .08 & .27 & .00 & .09 & -.01 & -.28 & .00 & -.09 & -.23 & -.38 \\
\hline France & .17 & -.08 & .01 & .07 & -.02 & -.06 & .07 & -.07 & .01 & .11 & -.05 & -.16 \\
\hline Germany & .52 & .06 & -.00 & .04 & .03 & .03 & -.18 & -.43 & -.18 & -.03 & .10 & .04 \\
\hline Greece & .07 & -1.29 & 1.35 & .53 & -.30 & -.28 & -1.39 & -1.63 & 1.45 & .84 & .04 & .61 \\
\hline Italy & .14 & .15 & -.07 & .00 & -.01 & -.25 & -.25 & -.14 & .12 & .21 & .14 & -.03 \\
\hline Japan & .56 & -.20 & .07 & .62 & -.09 & -.60 & -.32 & -.35 & .95 & .33 & -.90 & -.05 \\
\hline Luxembourg & .11 & .04 & -.23 & .05 & .11 & -.00 & .01 & -.17 & .01 & -.01 & .03 & .04 \\
\hline Netherlands & .17 & .21 & .23 & .73 & -.40 & -.25 & -.57 & .03 & .38 & -.03 & -.25 & -.25 \\
\hline Norway & 1.02 & -.11 & .34 & -.32 & -.21 & .01 & .48 & -.57 & .11 & -.18 & -.19 & -.38 \\
\hline Portugal & .19 & .19 & .80 & -.31 & -1.13 & -.83 & -.29 & .41 & .46 & .21 & .14 & .17 \\
\hline Spain & .27 & -.40 & .09 & .15 & -.12 & -.49 & .15 & .08 & -.01 & -.02 & .16 & .12 \\
\hline Sweden & .55 & .24 & -.15 & .09 & -.30 & .04 & -.13 & .10 & -.05 & -.09 & -.18 & -.12 \\
\hline Switzerland & .07 & -.05 & -.11 & -.21 & .24 & .04 & -.20 & .05 & -.09 & -.03 & .39 & -.10 \\
\hline Turkey & 2.04 & .12 & 1.53 & 1.29 & .64 & -3.76 & .34 & -1.18 & 1.12 & .29 & -.70 & -1.71 \\
\hline United King. & .14 & -.05 & -.04 & 1.06 & -.08 & -.06 & -.34 & -.32 & -.28 & .08 & .00 & -.10 \\
\hline United States & -.07 & .06 & -.01 & .08 & .03 & .10 & .07 & -.05 & .04 & -.06 & -.09 & -.09 \\
\hline Yugoslavia & 1.15 & -.08 & -.02 & -.35 & .04 & .09 & -1.82 & -1.15 & .12 & 1.08 & 1.13 & -.17 \\
\hline
\end{tabular}




\begin{tabular}{|c|c|c|c|c|c|c|c|c|c|c|c|c|}
\hline \multicolumn{13}{|c|}{ Table 6: Nominal Interest Rate, Changes in Levels (Monthly) } \\
\hline & \multicolumn{3}{|c|}{ Sample Period } & \multicolumn{3}{|c|}{ Std. Dev. of Seasonals } & \multicolumn{3}{|c|}{ Std. Dev. of Residuals } & \multicolumn{3}{|c|}{$R^{2}$} \\
\hline Belgium & \multicolumn{3}{|c|}{ 1960:2-1987:12 } & \multicolumn{3}{|c|}{.11} & \multicolumn{3}{|c|}{.54} & \multicolumn{3}{|c|}{.040} \\
\hline Canada & \multicolumn{3}{|c|}{ 1960:2 -1987:12 } & \multicolumn{3}{|c|}{.07} & \multicolumn{3}{|c|}{.53} & \multicolumn{3}{|c|}{.018} \\
\hline France & \multicolumn{3}{|c|}{ 1971:2-1987:12 } & \multicolumn{3}{|c|}{.15} & \multicolumn{3}{|c|}{.66} & \multicolumn{3}{|c|}{.047} \\
\hline Germany & \multicolumn{3}{|c|}{ 1971:7 -1987:12 } & \multicolumn{3}{|c|}{.08} & \multicolumn{3}{|c|}{.28} & \multicolumn{3}{|c|}{.070} \\
\hline Ireland & \multicolumn{3}{|c|}{ 1971:4 -1987:12 } & \multicolumn{3}{|c|}{.26} & \multicolumn{3}{|c|}{.76} & \multicolumn{3}{|c|}{.105} \\
\hline Japan & \multicolumn{3}{|c|}{$1960: 2-1987: 12$} & \multicolumn{3}{|c|}{.03} & \multicolumn{3}{|c|}{.16} & \multicolumn{3}{|c|}{.027} \\
\hline Netherlands & \multicolumn{3}{|c|}{$1960: 2-1987: 12$} & & .15 & & & .54 & & & .069 & \\
\hline Sweden & 197 & $5-19$ & & & .12 & & & .66 & & & .032 & \\
\hline Switzerland & & $2-19$ & $7: 12$ & & .12 & & & .42 & & & .069 & \\
\hline United King. & 196 & $2-19$ & $7: 12$ & & .16 & & & .61 & & & .068 & \\
\hline United States & 196 & $2-19$ & $7: 12$ & & .06 & & & .66 & & & .009 & \\
\hline & $J A N$ & $F E B$ & $M A R$ & $A P R$ & $M A Y$ & $J U N$ & $J U L$ & $A U G$ & $S E P$ & $O C T$ & $\mathrm{NOV}$ & $D E C$ \\
\hline Belgium & -.19 & -.09 & .05 & -.09 & -.09 & -.03 & .16 & .01 & .06 & .11 & -.09 & .18 \\
\hline Canada & -.04 & .08 & -.07 & .08 & -.07 & .09 & .09 & -.06 & -.00 & -.11 & -.05 & .07 \\
\hline France & -.03 & -.02 & .00 & -.22 & .18 & .19 & -.16 & -.02 & .29 & -.16 & -.07 & .02 \\
\hline Germany & .01 & -.04 & -.05 & -.07 & .10 & .12 & .07 & -.05 & -.00 & -.05 & .10 & -.13 \\
\hline Ireland & .05 & -.19 & -.19 & -.58 & .05 & .02 & .05 & .23 & -.27 & .16 & .28 & .40 \\
\hline Japan & .02 & -.02 & -.04 & .06 & .00 & -.02 & .01 & .02 & -.02 & -.01 & -.03 & .02 \\
\hline Netherlands & -.30 & -.17 & -.11 & -.12 & .15 & .13 & .13 & .11 & .02 & .19 & -.09 & .08 \\
\hline Sweden & .07 & -.07 & -.08 & .36 & -.02 & .05 & -.07 & -.02 & .05 & -.08 & -.14 & -.06 \\
\hline Switzerland & -.30 & -.02 & -.01 & .02 & .14 & .08 & -.06 & -.13 & .09 & .08 & .07 & .04 \\
\hline United King. & -.11 & -.01 & -.34 & -.17 & .04 & .09 & .24 & -.12 & .03 & .07 & .27 & .00 \\
\hline United States & -.00 & .01 & -.01 & -.11 & -.01 & -.02 & .12 & .10 & -.10 & -.02 & .01 & .03 \\
\hline
\end{tabular}

\begin{tabular}{|c|c|c|c|c|c|c|c|c|c|c|c|c|}
\hline \multicolumn{13}{|c|}{ Table 7: Real Interest Rate, Levels (Monthly) } \\
\hline & \multicolumn{3}{|c|}{ Sample Period } & \multicolumn{3}{|c|}{ Std. Dev. of Seasonals } & \multicolumn{3}{|c|}{ Std. Dev. of Residuals } & \multicolumn{3}{|c|}{$R^{2}$} \\
\hline Belgium & \multicolumn{3}{|c|}{ 1960:1 -1987:9 } & \multicolumn{3}{|c|}{.13} & \multicolumn{3}{|c|}{3.01} & \multicolumn{3}{|c|}{.002} \\
\hline Canada & \multicolumn{3}{|c|}{$1960: 1-1987: 9$} & \multicolumn{3}{|c|}{.27} & \multicolumn{3}{|c|}{3.01} & \multicolumn{3}{|c|}{.008} \\
\hline France & \multicolumn{3}{|c|}{ 1971:1 -1987:11 } & \multicolumn{3}{|c|}{.16} & \multicolumn{3}{|c|}{2.65} & \multicolumn{3}{|c|}{.004} \\
\hline Germany & \multicolumn{3}{|c|}{$1971: 6-1987: 9$} & \multicolumn{3}{|c|}{.36} & \multicolumn{3}{|c|}{1.39} & \multicolumn{3}{|c|}{.061} \\
\hline Japan & \multicolumn{3}{|c|}{ 1960:1 -1987:10 } & \multicolumn{3}{|c|}{.72} & \multicolumn{3}{|c|}{1.22} & \multicolumn{3}{|c|}{.255} \\
\hline Netherlands & \multicolumn{3}{|c|}{ 1960:1 -1987:9 } & \multicolumn{3}{|c|}{.59} & \multicolumn{3}{|c|}{2.47} & \multicolumn{3}{|c|}{.053} \\
\hline Sweden & \multicolumn{3}{|c|}{ 1970:4 -1985:12 } & \multicolumn{3}{|c|}{.46} & & 2.46 & & & .034 & \\
\hline Switzerland & 196 & $: 1-19$ & & & .25 & & & 1.64 & & & .022 & \\
\hline United King. & 196 & $: 1-19$ & & & .60 & & & 2.50 & & & .053 & \\
\hline United States & 196 & $: 1-19$ & & & .19 & & & 2.34 & & & .007 & \\
\hline & $J A N$ & $F E B$ & $M A R$ & $\overline{A P R}$ & $M A Y$ & JUN & $J U L$ & $A U G$ & $S E P$ & $O C T$ & NOV & $D E C$ \\
\hline Belgium & .05 & .07 & -.01 & -.17 & -.13 & -.21 & .11 & .02 & .20 & .05 & -.13 & .15 \\
\hline Canada & -.14 & -.12 & -.31 & -.39 & -.36 & .22 & .50 & .35 & .13 & .06 & .06 & -.00 \\
\hline France & .01 & -.14 & -.27 & -.30 & .00 & -.02 & .05 & -.02 & .17 & .24 & .22 & .06 \\
\hline Germany & -.11 & -.04 & -.22 & -.03 & .38 & .64 & .54 & .16 & .00 & -.43 & -.43 & -.46 \\
\hline Japan & .19 & -.66 & -.55 & .72 & .94 & .66 & -.61 & -1.27 & .54 & .90 & -.51 & -.35 \\
\hline Netherlands & -1.17 & -.73 & -.35 & .83 & .55 & .05 & -.36 & .03 & .68 & .64 & .11 & -.27 \\
\hline Sweden & .14 & .38 & .32 & .25 & .51 & .21 & .09 & .15 & .24 & -.55 & -.97 & -.76 \\
\hline Switzerland & .25 & -.06 & -.23 & -.21 & .12 & .33 & .10 & -.36 & -.25 & -.28 & .27 & .33 \\
\hline United King. & -.88 & -.85 & -1.13 & .17 & .49 & .76 & .62 & .18 & .06 & -.01 & .30 & .28 \\
\hline United States & -.11 & -.07 & -.19 & -.29 & -.22 & -.18 & .07 & .23 & .26 & .28 & .13 & .09 \\
\hline
\end{tabular}




\begin{tabular}{|l|c|c|c|c|r|r|r|r|}
\hline \multicolumn{7}{|c|}{ Table 8: Employment, Log Growth Rates (Quarterly) } \\
\hline & Sample Period & Std. Dev. of Seasonals & Std. Dev. of Residuals & \multicolumn{1}{c|}{$\boldsymbol{R}^{2}$} & \multicolumn{1}{c|}{ Q1 } & \multicolumn{1}{|c|}{ Q2 } & \multicolumn{1}{c|}{ Q3 } & \multicolumn{1}{c|}{ Q4 } \\
\hline Australia & $1965: 2-1987: 3$ & .43 & .65 & .307 & -.23 & .17 & -.54 & .61 \\
Austria & $1973: 2-1987: 3$ & 1.53 & .46 & .917 & -.64 & 1.45 & 1.39 & -2.20 \\
Canada & $1965: 2-1987: 3$ & .38 & .81 & .946 & -3.18 & 3.76 & 2.94 & -3.52 \\
Finland & $1970: 2-1987: 2$ & 3.70 & .88 & .947 & -2.08 & 4.97 & 1.78 & -4.67 \\
Germany & $1965: 2-1987: 3$ & .85 & .62 & .651 & -1.28 & .71 & .82 & -.25 \\
Italy & $1970: 2-1984: 4$ & .87 & .76 & .567 & -1.16 & .22 & 1.25 & -.31 \\
Japan & $1965: 2-1987: 3$ & .58 & .71 & .404 & -.80 & .65 & -.29 & .44 \\
Sweden & $1970: 2-1987: 3$ & 1.14 & .63 & .765 & -1.00 & 1.22 & 1.03 & -1.25 \\
United King. & $1965: 2-1987: 2$ & .51 & .61 & .409 & -.71 & .70 & .13 & -.11 \\
United States & $1948: 2-1985: 4$ & 1.50 & .89 & .739 & -2.49 & 1.46 & .25 & .79 \\
\hline
\end{tabular}

\begin{tabular}{|l|l|l|r|r|r|r|r|r|}
\hline \multicolumn{7}{|c|}{ Table 9: Total Hours in Manufacturing, Log Growth Rates (Quarterly) } \\
\hline & Sample Period & Std. Dev. of Seasonals & Std. Dev. of Residuals & \multicolumn{1}{c|}{$\boldsymbol{R}^{2}$} & \multicolumn{1}{c|}{ Q1 } & \multicolumn{1}{|c|}{ Q2 } & \multicolumn{1}{c|}{ Q3 } & \multicolumn{1}{c|}{ Q4 } \\
\hline Austria & $1969: 2-1987: 3$ & 2.79 & 2.05 & .649 & -1.75 & -.11 & -2.70 & 4.56 \\
Austria & $1965: 2-1987: 3$ & 3.48 & 1.82 & .954 & -1.52 & -1.53 & -2.90 & 5.95 \\
Canada & $1960: 2-1987: 3$ & 2.16 & 1.80 & .588 & -.75 & 2.93 & .76 & -2.95 \\
Germany & $1965: 2-1987: 3$ & 2.85 & 2.67 & .533 & -2.66 & -1.08 & -1.10 & 4.83 \\
Greece & $1962: 2-1987: 3$ & 2.13 & 3.18 & .310 & -3.58 & 1.81 & 1.39 & .38 \\
Japan & $1960: 2-1987: 3$ & 5.17 & 1.37 & .934 & -6.48 & 7.62 & -2.10 & .96 \\
Norway & $1960: 2-1970: 4$ & 7.61 & 3.13 & .855 & -1.36 & -5.86 & -5.30 & 12.52 \\
Sweden & $1968: 2-1986: 2$ & 11.83 & 3.13 & .935 & -3.19 & -2.68 & -13.27 & 19.14 \\
Sweden & $1968: 2-1986: 2$ & 11.82 & 3.16 & .933 & -3.17 & -2.75 & -13.23 & 19.98 \\
United States & $1960: 2-1987: 4$ & 1.67 & 1.82 & .457 & -2.87 & 1.39 & .82 & .66 \\
\hline
\end{tabular}




\begin{tabular}{|l|c|c|c|}
\hline \multicolumn{4}{|c|}{ Table 10: Relation Between Money and Output, } \\
Log Growth Rates (Quarterly) \\
\hline & Sample Period & Coefficient & Standard Error \\
\hline Argentina & $1977: 2-1987: 2$ & .45 & $(.33)$ \\
Australia & $1960: 2-1987: 3$ & .23 & $(.03)$ \\
Austria & $1973: 2-1987: 3$ & .31 & $(.04)$ \\
Canada & $1961: 2-1987: 3$ & .36 & $(.04)$ \\
Finland & $1970: 2-1987: 2$ & .65 & $(.12)$ \\
Germany & $1968: 2-1987: 3$ & .68 & $(.06)$ \\
Italy & $1970: 2-1984: 4$ & .68 & $(.08)$ \\
Japan & $1965: 2-1987: 1$ & .39 & $(.02)$ \\
Netherlands & $1977: 2-1987: 3$ & .52 & $(.06)$ \\
Norway & $1978: 2-1987: 3$ & .35 & $(.22)$ \\
Sweden & $1970: 2-1987: 3$ & .12 & $(.05)$ \\
Taiwan & $1968: 2-1987: 3$ &. .36 & $(.11)$ \\
United King. & $1963: 2-1987: 3$ & .54 & $(.14)$ \\
United States & $1948: 2-1985: 4$ & .13 & $(.02)$ \\
\hline
\end{tabular}

\begin{tabular}{|l|c|c|c|}
\hline \multicolumn{5}{|c|}{ Table 11: Relation Between Money and Industrial Production, } \\
& Log Growth Rates (Monthly) \\
\hline & Sample Period & Coefficient & Standard Error \\
\hline Australia & $1963: 2-1987: 9$ & -.03 & $(.01)$ \\
Austria & $1960: 2-1987: 11$ & .15 & $(.02)$ \\
Belgium & $1976: 1-1987: 9$ & .02 & $(.01)$ \\
Canada & $1960: 2-1987: 11$ & -.18 & $(.02)$ \\
Finland & $1960: 2-1987: 11$ & .02 & $(.01)$ \\
France & $1970: 1-1987: 11$ & .04 & $(.01)$ \\
Germany & $1960: 2-1987: 11$ & .14 & $(.01)$ \\
Greece & $1962: 2-1987: 10$ & .13 & $(.04)$ \\
Ireland & $1976: 11-1987: 10$ & .01 & $(.03)$ \\
Italy & $1962: 1-1987: 11$ & .01 & $(.00)$ \\
Japan & $1960: 2-1987: 11$ & .43 & $(.04)$ \\
Netherlands & $1960: 2-1987: 10$ & -.02 & $(.01)$ \\
Norway & $1960: 2-1987: 10$ & -.01 & $(.00)$ \\
Portugal & $1979: 1-1987: 7$ & -.07 & $(.01)$ \\
Spain & $1961: 2-1987: 9$ & .04 & $(.00)$ \\
Sweden & $1960: 2-1987: 11$ & -.01 & $(.00)$ \\
United King. & $1971: 7-1987: 11$ & -.05 & $(.03)$ \\
United States & $1960: 2-1987: 12$ & -.25 & $(.02)$ \\
Yugoslavia & $1964: 11-1987: 10$ & -.07 & $(.02)$ \\
\hline
\end{tabular}




\begin{tabular}{|l|l|c|c|}
\hline \multicolumn{5}{|c|}{ Table 12: Relation Between Money and Retail Sales, } \\
\multicolumn{1}{|c|}{ Log Growth Rates (Monthly) } \\
\hline Austria & Sample Period & Coefficient & Standard Error \\
Belgium & $1960: 2-1987: 10$ & .03 & $(.01)$ \\
Canada & $1976: 1-1987: 9$ & .12 & $(.01)$ \\
Denmark & $1960: 2-1987: 11$ & .11 & $(.01)$ \\
Finland & $1970: 3-1987: 11$ & .21 & $(.03)$ \\
France & $1960: 2-1987: 9$ & .14 & $(.02)$ \\
Germany & $1970: 1-1987: 11$ & .11 & $(.01)$ \\
Greece & $1960: 2-1987: 11$ & .12 & $(.01)$ \\
Italy & $1974: 7-1987: 10$ & .34 & $(.05)$ \\
Japan & $1970: 2-1987: 8$ & .12 & $(.01)$ \\
Netherlands & $1960: 2-1987: 10$ & .21 & $(.01)$ \\
Norway & $1960: 2-1987: 10$ & .05 & $(.01)$ \\
Spain & $1960: 2-1987: 10$ & .06 & $(.01)$ \\
Sweden & $1965: 2-1987: 9$ & .05 & $(.01)$ \\
Switzerland & $1973: 2-1987: 10$ & .02 & $(.02)$ \\
United King. & $1960: 2-1987: 10$ & .11 & $(.01)$ \\
United States & $1971: 7-1987: 11$ & .09 & $(.01)$ \\
Yugoslavia & $1960: 2-1987: 12$ & .04 & $(.00)$ \\
& $1964: 11-1987: 10$ &. .01 & $(.01)$ \\
\hline
\end{tabular}

\begin{tabular}{|l|c|c|c|}
\hline \multicolumn{5}{|c|}{ Table 13: Relation Between Industrial Production and Hours, } \\
& Log Growth Rates (Quarterly) \\
\hline & Sample Period & Coefficient & Standard Error \\
\hline Austria (HH) & $1969: 2-1987: 3$ & 2.91 & $(.18)$ \\
Austria (EST) & $1965: 2-1987: 3$ & 1.95 & $(.10)$ \\
Canada & $1960: 2-1987: 3$ & -.02 & $(.15)$ \\
Germany & $1965: 2-1987: 3$ & 2.36 & $(.12)$ \\
Greece & $1962: 2-1987: 3$ & 1.68 & $(.23)$ \\
Japan & $1960: 2-1987: 3$ & .31 & $(.06)$ \\
Norway (males) & $1960: 2-1970: 4$ & 1.13 & $(.07)$ \\
Sweden (HH) & $1968: 2-1986: 2$ & 1.53 & $(.04)$ \\
Sweden (EST) & $1968: 2-1986: 2$ & 1.53 & $(.04)$ \\
United States & $1960: 2-1987: 4$ & .51 & $(.10)$ \\
\hline
\end{tabular}




\begin{tabular}{|c|c|c|c|c|c|c|c|c|c|c|c|c|}
\hline \multicolumn{13}{|c|}{ Table 14: Univariate Cross Sectional Regressions (Weighted) } \\
\hline & \multicolumn{2}{|c|}{ Indus. Prod. } & \multicolumn{2}{|c|}{ Retail Sales } & \multicolumn{2}{|c|}{ Money } & \multicolumn{2}{|c|}{ Prices } & \multicolumn{2}{|c|}{ Nom. Rates } & \multicolumn{2}{|c|}{ Real Rates } \\
\hline & Coeff & t-stat & Coeff & t-stat & Coeff & t-stat & Coeff & t-stat & Coeff & t-stat & Coeff & t-stat \\
\hline $\begin{array}{l}\text { Seasonal } \\
\text { Std. Dev. }\end{array}$ & .18 & 3.12 & .21 & 1.90 & .64 & 4.54 & 1.94 & 7.80 & 1.97 & 2.95 & -1.26 & -1.23 \\
\hline $\bar{R}^{2}$ & \multicolumn{2}{|c|}{.349} & \multicolumn{2}{|c|}{.225} & \multicolumn{2}{|c|}{.618} & \multicolumn{2}{|c|}{.766} & \multicolumn{2}{|c|}{.590} & \multicolumn{2}{|c|}{.151} \\
\hline
\end{tabular}

\begin{tabular}{|c|c|c|c|c|c|c|c|c|c|c|c|c|}
\hline & \multicolumn{2}{|c|}{ Indus. Prod. } & \multicolumn{2}{|c|}{ Retail Sales } & \multicolumn{2}{|c|}{ Money } & \multicolumn{2}{|c|}{ Prices } & \multicolumn{2}{|c|}{ Nom. Rates } & \multicolumn{2}{|c|}{ Real Rates } \\
\hline & Coeff & t-stat & Coeff & t-stat & Coeff & t-stat & Coeff & t-stat & Coeff & t-stat & Coeff & t-stat \\
\hline $\begin{array}{l}\text { Seasonal } \\
\text { Std. Dev. }\end{array}$ & $\begin{array}{r}.17 \\
(.02)\end{array}$ & $\begin{array}{l}2.76 \\
(.32)\end{array}$ & $\begin{array}{r}.21 \\
(.05)\end{array}$ & $\begin{array}{l}2.09 \\
(.71)\end{array}$ & $\begin{array}{r}.39 \\
(.15) \\
\end{array}$ & $\begin{array}{r}2.57 \\
(1.29) \\
\end{array}$ & $\begin{array}{l}1.27 \\
(.49) \\
\end{array}$ & $\begin{array}{r}2.86 \\
(1.75) \\
\end{array}$ & $\begin{array}{l}3.47 \\
(.61) \\
\end{array}$ & $\begin{array}{r}4.92 \\
(2.50) \\
\end{array}$ & $\begin{array}{r}-1.07 \\
(.57) \\
\end{array}$ & $\begin{array}{l}-1.58 \\
(1.19) \\
\end{array}$ \\
\hline AREA & $\begin{array}{l}-.17 \\
(.07)\end{array}$ & $\begin{array}{r}-1.13 \\
(.49)\end{array}$ & $\begin{array}{l}-.10 \\
(.08)\end{array}$ & $\begin{array}{l}-.71 \\
(.52)\end{array}$ & $\begin{array}{l}-.07 \\
(.06)\end{array}$ & $\begin{array}{l}-.99 \\
(.90)\end{array}$ & $\begin{array}{r}.00 \\
(.02)\end{array}$ & $\begin{array}{r}.02 \\
(.68)\end{array}$ & $\begin{array}{r}.02 \\
(.01)\end{array}$ & $\begin{array}{l}1.33 \\
(.85)\end{array}$ & $\begin{array}{l}-.02 \\
(.06)\end{array}$ & $\begin{array}{r}-.47 \\
(1.89)\end{array}$ \\
\hline POP & $\begin{array}{l}-5.17 \\
(3.49)\end{array}$ & $\begin{array}{l}-.61 \\
(.39)\end{array}$ & $\begin{array}{r}-10.52 \\
(2.66)\end{array}$ & $\begin{array}{r}-1.60 \\
(.39)\end{array}$ & $\begin{array}{l}-4.71 \\
(2.27)\end{array}$ & $\begin{array}{r}-1.38 \\
(.70)\end{array}$ & $\begin{array}{l}-.97 \\
(.73)\end{array}$ & $\begin{array}{l}-.53 \\
(.44)\end{array}$ & $\begin{array}{r}.66 \\
(.35)\end{array}$ & $\begin{array}{l}1.21 \\
(.79)\end{array}$ & $\begin{array}{l}-2.64 \\
(2.08)\end{array}$ & $\begin{array}{r}-1.19 \\
(.99)\end{array}$ \\
\hline TOTGNP & $\begin{array}{l}-.42 \\
(.23)\end{array}$ & $\begin{array}{l}-.79 \\
(.42)\end{array}$ & $\begin{array}{l}-.60 \\
(.18)\end{array}$ & $\begin{array}{r}-1.40 \\
(.40)\end{array}$ & $\begin{array}{l}-.30 \\
(.14)\end{array}$ & $\begin{array}{r}-1.36 \\
(.66)\end{array}$ & $\begin{array}{l}-.06 \\
(.05)\end{array}$ & $\begin{array}{l}-.50 \\
(.43)\end{array}$ & $\begin{array}{r}.05 \\
(.02)\end{array}$ & $\begin{array}{l}1.53 \\
(.88)\end{array}$ & $\begin{array}{l}-.15 \\
(.12)\end{array}$ & $\begin{array}{r}-1.23 \\
(.99)\end{array}$ \\
\hline AGRSHR & $\begin{array}{r}.02 \\
(.09)\end{array}$ & $\begin{array}{r}.20 \\
(.68)\end{array}$ & $\begin{array}{r}.12 \\
(.18)\end{array}$ & $\begin{array}{r}1.33 \\
(1.03)\end{array}$ & $\begin{array}{r}.06 \\
(.04)\end{array}$ & $\begin{array}{r}1.32 \\
(1.01)\end{array}$ & $\begin{array}{r}.02 \\
(.04)\end{array}$ & $\begin{array}{r}.29 \\
(.65)\end{array}$ & $\begin{array}{l}-.02 \\
(.02)\end{array}$ & $\begin{array}{r}-1.06 \\
(.74)\end{array}$ & $\begin{array}{r}.26 \\
(.21)\end{array}$ & $\begin{array}{r}.79 \\
(.88)\end{array}$ \\
\hline MANSHR & $\begin{array}{l}-.01 \\
(.05)\end{array}$ & $\begin{array}{c}-.03 \\
(.52)\end{array}$ & $\begin{array}{l}-.09 \\
(.03)\end{array}$ & $\begin{array}{r}-1.18 \\
(.35)\end{array}$ & $\begin{array}{l}-.06 \\
(.02)\end{array}$ & $\begin{array}{r}-1.56 \\
(.42)\end{array}$ & $\begin{array}{r}.00 \\
(.01)\end{array}$ & $\begin{array}{l}-.07 \\
(.51)\end{array}$ & $\begin{array}{l}-.01 \\
(.01)\end{array}$ & $\begin{array}{r}-1.44 \\
(.91)\end{array}$ & $\begin{array}{l}-.10 \\
(.02)\end{array}$ & $\begin{array}{l}-5.51 \\
(1.63)\end{array}$ \\
\hline INDSHR & $\begin{array}{r}.07 \\
(.04)\end{array}$ & $\begin{array}{r}.82 \\
(.49)\end{array}$ & $\begin{array}{r}.02 \\
(.04)\end{array}$ & $\begin{array}{r}.26 \\
(.50)\end{array}$ & $\begin{array}{l}-.04 \\
(.02)\end{array}$ & $\begin{array}{r}-1.35 \\
(.72)\end{array}$ & $\begin{array}{r}.03 \\
(.00)\end{array}$ & $\begin{array}{l}1.35 \\
(.26)\end{array}$ & $\begin{array}{l}-.02 \\
(.00)\end{array}$ & $\begin{array}{l}-4.95 \\
(1.56)\end{array}$ & $\begin{array}{l}-.14 \\
(.02)\end{array}$ & $\begin{array}{l}-4.39 \\
(2.85)\end{array}$ \\
\hline SERSHR & $\begin{array}{l}-.05 \\
(.05)\end{array}$ & $\begin{array}{l}-.83 \\
(.75)\end{array}$ & $\begin{array}{l}-.08 \\
(.06)\end{array}$ & $\begin{array}{r}-1.16 \\
(.87)\end{array}$ & $\begin{array}{r}.01 \\
(.02)\end{array}$ & $\begin{array}{r}.46 \\
(.87)\end{array}$ & $\begin{array}{l}-.04 \\
(.01)\end{array}$ & $\begin{array}{r}-1.68 \\
(.40)\end{array}$ & $\begin{array}{r}.02 \\
(.00)\end{array}$ & $\begin{array}{l}3.28 \\
(.88)\end{array}$ & $\begin{array}{r}.14 \\
(.03) \\
\end{array}$ & $\begin{array}{r}3.38 \\
(1.27) \\
\end{array}$ \\
\hline PCGNP & $\begin{array}{l}-.12 \\
(.03)\end{array}$ & $\begin{array}{l}-.80 \\
(.21)\end{array}$ & $\begin{array}{l}-.16 \\
(.05)\end{array}$ & $\begin{array}{r}-1.35 \\
(.54)\end{array}$ & $\begin{array}{l}-.03 \\
(.07)\end{array}$ & $\begin{array}{l}-.37 \\
(.88)\end{array}$ & $\begin{array}{l}-.02 \\
(.02)\end{array}$ & $\begin{array}{l}-.65 \\
(.41)\end{array}$ & $\begin{array}{r}.04 \\
(.01)\end{array}$ & $\begin{array}{l}1.69 \\
(.64)\end{array}$ & $\begin{array}{l}-.12 \\
(.08)\end{array}$ & $\begin{array}{l}-2.97 \\
(3.07)\end{array}$ \\
\hline LIFE & $\begin{array}{l}-.06 \\
(.05)\end{array}$ & $\begin{array}{l}-.25 \\
(.21)\end{array}$ & $\begin{array}{c}-.02 \\
(.22)\end{array}$ & $\begin{array}{l}-.38 \\
(.97)\end{array}$ & $\begin{array}{l}-.14 \\
(.03)\end{array}$ & $\begin{array}{r}-2.01 \\
(.55)\end{array}$ & $\begin{array}{r}.02 \\
(.02)\end{array}$ & $\begin{array}{r}.21 \\
(.32)\end{array}$ & $\begin{array}{r}.01 \\
(.02)\end{array}$ & $\begin{array}{r}.34 \\
(.54)\end{array}$ & $\begin{array}{l}-.04 \\
(.10)\end{array}$ & $\begin{array}{l}-.08 \\
(.31)\end{array}$ \\
\hline BIRTH & $\begin{array}{l}-.41 \\
(.10)\end{array}$ & $\begin{array}{r}-1.79 \\
(.51)\end{array}$ & $\begin{array}{r}.28 \\
(.14)\end{array}$ & $\begin{array}{l}1.12 \\
(.55)\end{array}$ & $\begin{array}{r}.13 \\
(.03)\end{array}$ & $\begin{array}{l}2.96 \\
(.92)\end{array}$ & $\begin{array}{r}.07 \\
(.02)\end{array}$ & $\begin{array}{r}2.37 \\
(1.29)\end{array}$ & $\begin{array}{r}.02 \\
(.02)\end{array}$ & $\begin{array}{l}1.10 \\
(.73)\end{array}$ & $\begin{array}{r}.15 \\
(.07)\end{array}$ & $\begin{array}{l}1.69 \\
(.70)\end{array}$ \\
\hline INFMOR & $\begin{array}{r}.15 \\
(.13)\end{array}$ & $\begin{array}{l}1.15 \\
(.56)\end{array}$ & $\begin{array}{r}.19 \\
(.07)\end{array}$ & $\begin{array}{l}2.11 \\
(.93)\end{array}$ & $\begin{array}{r}.03 \\
(.00)\end{array}$ & $\begin{array}{l}2.56 \\
(.52)\end{array}$ & $\begin{array}{r}.02 \\
(.00)\end{array}$ & $\begin{array}{r}2.43 \\
(1.45)\end{array}$ & $\begin{array}{l}-.01 \\
(.01)\end{array}$ & $\begin{array}{l}-.33 \\
(.27)\end{array}$ & $\begin{array}{r}.02 \\
(.04)\end{array}$ & $\begin{array}{r}.24 \\
(.38)\end{array}$ \\
\hline POPMD & $\begin{array}{l}-3.15 \\
(2.18)\end{array}$ & $\begin{array}{l}-.92 \\
(.62)\end{array}$ & $\begin{array}{c}-2.68 \\
(1.75)\end{array}$ & $\begin{array}{r}-1.01 \\
(.85)\end{array}$ & $\begin{array}{l}1.84 \\
(.41)\end{array}$ & $\begin{array}{l}3.05 \\
(.81)\end{array}$ & $\begin{array}{r}.87 \\
(.25)\end{array}$ & $\begin{array}{l}1.65 \\
(.89)\end{array}$ & $\begin{array}{l}-.17 \\
(.22)\end{array}$ & $\begin{array}{l}-.46 \\
(.66)\end{array}$ & $\begin{array}{l}1.90 \\
(.82)\end{array}$ & $\begin{array}{l}1.47 \\
(.80)\end{array}$ \\
\hline CALOR & $\begin{array}{r}.69 \\
(1.13)\end{array}$ & $\begin{array}{r}.35 \\
(.56)\end{array}$ & $\begin{array}{l}1.80 \\
(.57)\end{array}$ & $\begin{array}{l}1.21 \\
(.32)\end{array}$ & $\begin{array}{r}-1.18 \\
(.26)\end{array}$ & $\begin{array}{r}-1.81 \\
(.61)\end{array}$ & $\begin{array}{l}-.14 \\
(.22)\end{array}$ & $\begin{array}{c}-.34 \\
(.56)\end{array}$ & $\begin{array}{r}.04 \\
(.04)\end{array}$ & $\begin{array}{r}.27 \\
(.30)\end{array}$ & $\begin{array}{l}-.02 \\
(.33)\end{array}$ & $\begin{array}{l}-.12 \\
(.47)\end{array}$ \\
\hline SCHOOL & $\begin{array}{l}-.08 \\
(.02)\end{array}$ & $\begin{array}{r}-1.20 \\
(.28)\end{array}$ & $\begin{array}{r}.00 \\
(.04)\end{array}$ & $\begin{array}{r}.01 \\
(.65)\end{array}$ & $\begin{array}{l}-.05 \\
(.01)\end{array}$ & $\begin{array}{r}-1.93 \\
(.57)\end{array}$ & $\begin{array}{r}.01 \\
(.01)\end{array}$ & $\begin{array}{r}.55 \\
(.42)\end{array}$ & $\begin{array}{r}.01 \\
(.00)\end{array}$ & $\begin{array}{c}2.59 \\
(.95)\end{array}$ & $\begin{array}{l}-.02 \\
(.02)\end{array}$ & $\begin{array}{l}-1.67 \\
(1.35)\end{array}$ \\
\hline LFAGR & $\begin{array}{r}.07 \\
(.04)\end{array}$ & $\begin{array}{r}.92 \\
(.34)\end{array}$ & $\begin{array}{r}.13 \\
(.08)\end{array}$ & $\begin{array}{l}1.94 \\
(.53)\end{array}$ & $\begin{array}{r}.05 \\
(.01)\end{array}$ & $\begin{array}{l}2.53 \\
(.88)\end{array}$ & $\begin{array}{r}.04 \\
(.01)\end{array}$ & $\begin{array}{l}2.25 \\
(.40)\end{array}$ & $\begin{array}{r}.00 \\
(.02)\end{array}$ & $\begin{array}{r}.57 \\
(1.06)\end{array}$ & $\begin{array}{l}-.07 \\
(.10)\end{array}$ & $\begin{array}{r}-.90 \\
(1.27)\end{array}$ \\
\hline URBAN & $\begin{array}{c}-.03 \\
(.01) \\
\end{array}$ & $\begin{array}{l}-.97 \\
(.12) \\
\end{array}$ & $\begin{array}{r}-.05 \\
(.02) \\
\end{array}$ & $\begin{array}{r}-1.43 \\
(.61) \\
\end{array}$ & $\begin{array}{r}-.03 \\
(.01) \\
\end{array}$ & $\begin{array}{r}-2.47 \\
(.91) \\
\end{array}$ & $\begin{array}{c}-.01 \\
(.00) \\
\end{array}$ & $\begin{array}{r}-1.30 \\
(.32) \\
\end{array}$ & $\begin{array}{c}-.00 \\
(.00) \\
\end{array}$ & {$\left[\begin{array}{c}-1.12 \\
(.64)\end{array}\right.$} & $\begin{array}{r}.02 \\
(.02) \\
\end{array}$ & $\begin{array}{r}.52 \\
(.72) \\
\end{array}$ \\
\hline$\overline{\bar{R}^{2}}$ & \multicolumn{2}{|c|}{.402} & \multicolumn{2}{|c|}{.462} & \multicolumn{2}{|c|}{.752} & \multicolumn{2}{|c|}{.789} & \multicolumn{2}{|c|}{.796} & \multicolumn{2}{|c|}{.571} \\
\hline
\end{tabular}


Figure 1: Industrial Production

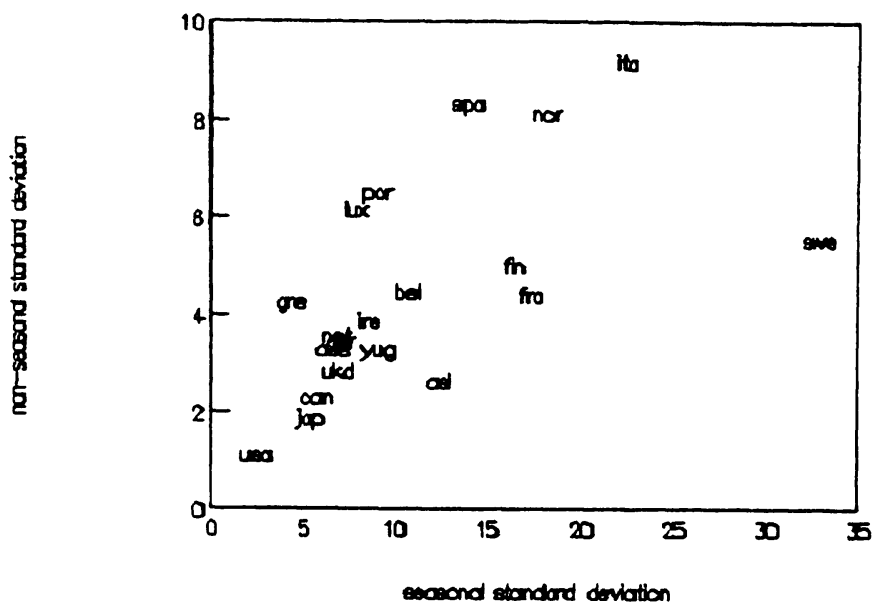

Figure 3: M1

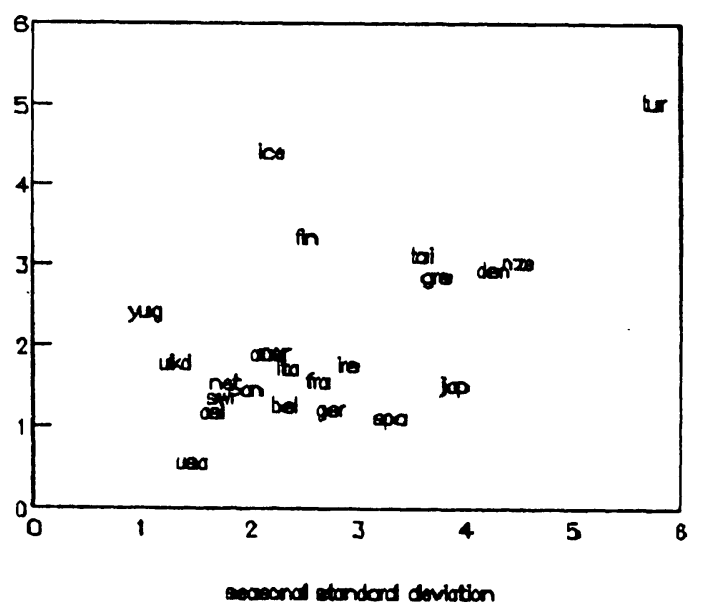

Figure 5: Nominal Interest Rate

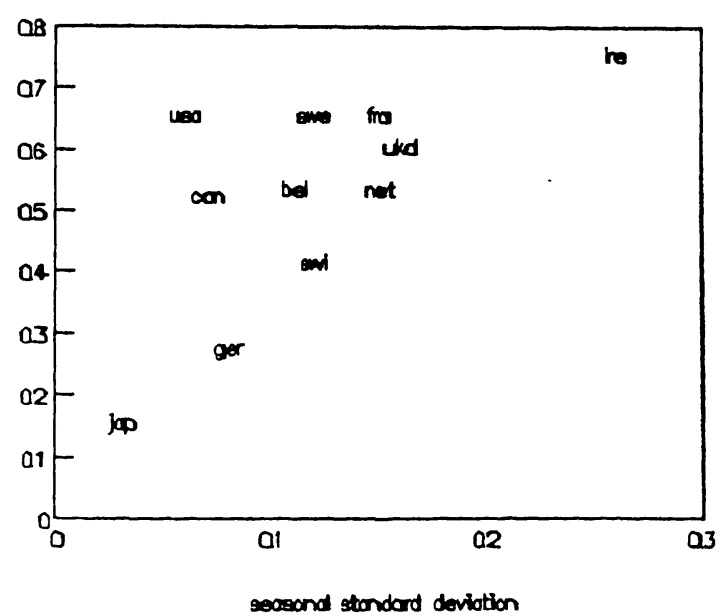

Figure 2: Retail Sales

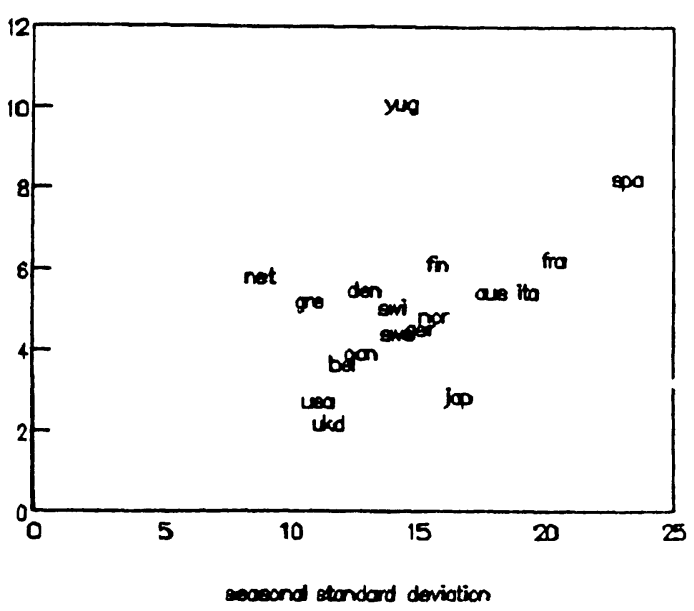

Figure 4: CPI

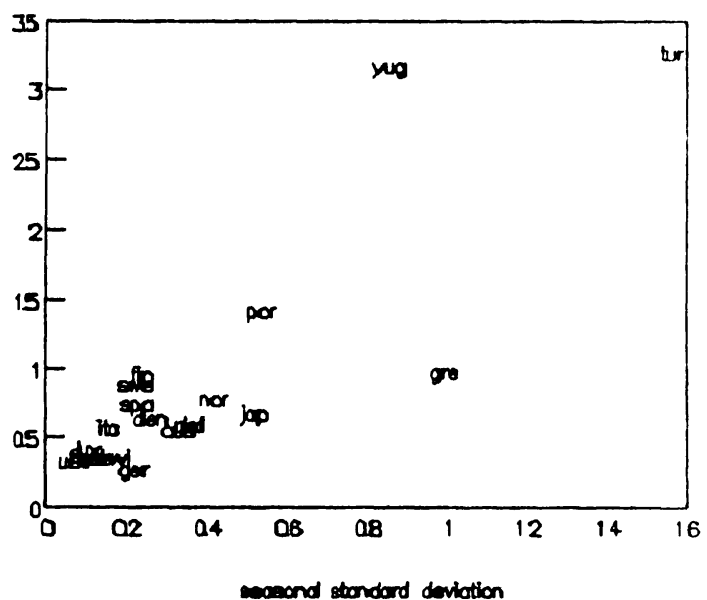

Figure 6: Real Interest Rate

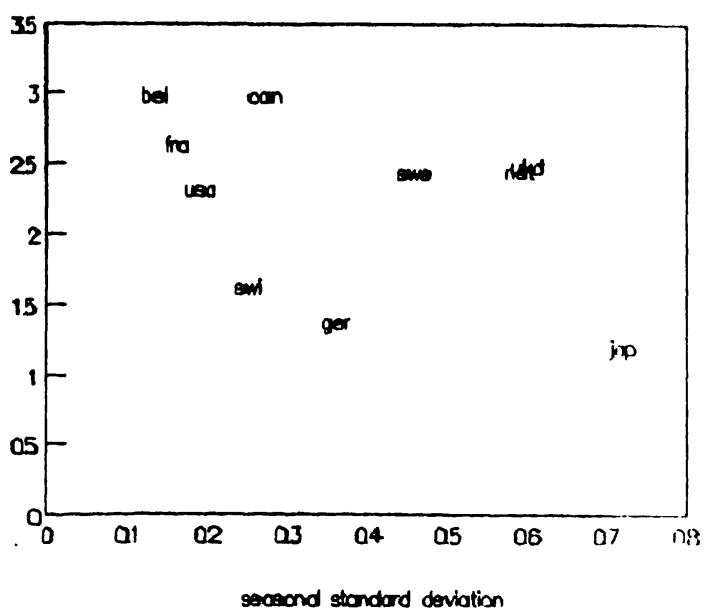


APPENDIX B: SUPPLEMENTARY TABLES

\begin{tabular}{|l|c|c|c|c|r|r|r|r|}
\hline \multicolumn{7}{|c|}{ Table B1: Real Consumption, Log Growth Rates (Quarterly) } \\
\hline & Sample Period & Std. Dev. of Seasonals & Std. Dev. of Residuals & \multicolumn{1}{c|}{$\boldsymbol{R}^{2}$} & \multicolumn{1}{|c|}{ Q1 } & \multicolumn{1}{c|}{ Q2 } & \multicolumn{1}{|c|}{ Q3 } & \multicolumn{1}{c|}{ Q4 } \\
\hline Argentina & $1977: 2-1987: 2$ & 4.19 & 4.83 & .429 & -2.00 & -5.06 & .97 & 6.10 \\
Australia & $1960: 2-1987: 3$ & 6.11 & 1.14 & .966 & -9.93 & 3.20 & .29 & 6.43 \\
Austria & $1973: 2-1987: 3$ & 12.32 & 2.40 & .963 & -20.89 & 6.64 & 3.10 & 11.15 \\
Canada & $1961: 2-1987: 3$ & 8.82 & 1.72 & .963 & -11.93 & 6.81 & -4.84 & 9.96 \\
Finland & $1970: 2-1987: 2$ & 4.36 & 2.54 & .747 & -5.07 & 3.85 & -3.51 & 4.73 \\
Germany & $1968: 2-1987: 3$ & 8.40 & 1.66 & .963 & -13.47 & 4.69 & -.25 & 9.02 \\
Italy & $1970: 2-1984: 4$ & 2.51 & 1.65 & .698 & -2.45 & .80 & 3.72 & -2.06 \\
Japan & $1965: 2-1987: 3$ & 9.57 & 1.89 & .962 & -15.48 & 1.92 & 2.61 & 10.95 \\
Norway & $1978: 2-1987: 4$ & 7.56 & 2.78 & .881 & -11.83 & 1.52 & .90 & 9.40 \\
Sweden & $1970: 2-1987: 3$ & 8.87 & 2.43 & .930 & -11.40 & 3.56 & -4.57 & 12.41 \\
Taiwan & $1961: 2-1987: 3$ & 9.72 & 2.63 & .932 & 12.44 & -14.21 & 3.64 & -1.87 \\
United King. & $1955: 2-1987: 3$ & 5.29 & 1.89 & .887 & -9.06 & 3.55 & 1.69 & 3.83 \\
United States & $1948: 2-1985: 4$ & 6.62 & 1.95 & .920 & -10.33 & 4.27 & -1.00 & 7.06 \\
\hline
\end{tabular}

\begin{tabular}{|l|c|r|c|r|r|r|r|r|}
\hline \multicolumn{7}{|c|}{ Table B2: Real Fixed Investment, Log Growth Rates (Quarterly) } \\
\hline & Sample Period & Std. Dev. of Seasonals & Std. Dev. of Residuals & \multicolumn{1}{c|}{$\boldsymbol{R}^{2}$} & \multicolumn{1}{|c|}{ Q1 } & \multicolumn{1}{|c|}{ Q2 } & \multicolumn{1}{|c|}{ Q3 } & \multicolumn{1}{|c|}{ Q4 } \\
\hline Argentina & $1977: 2-1987: 2$ & 10.34 & 6.95 & .689 & -16.98 & 9.65 & 5.93 & 1.40 \\
Australia & $1960: 2-1987: 2$ & 13.88 & 3.12 & .952 & -15.29 & 19.30 & -10.45 & 6.44 \\
Austria & $1973: 2-1987: 3$ & 30.35 & 3.18 & .989 & -47.32 & 35.36 & 12.71 & -.75 \\
Canada & $1961: 2-1987: 3$ & 12.54 & 3.32 & .935 & -15.70 & 17.50 & 4.95 & -6.75 \\
Finland & $1970: 2-1987: 2$ & 15.69 & 6.74 & .844 & -24.70 & -1.34 & 8.94 & 17.10 \\
Germany & $1968: 2-1987: 3$ & 18.29 & 4.60 & .941 & -27.88 & 22.84 & -.43 & 5.47 \\
Italy & $1970: 2-1984: 4$ & 5.67 & 2.81 & .803 & -1.55 & 2.41 & -8.04 & 7.19 \\
Japan & $1965: 2-1987: 3$ & 5.67 & 3.48 & .726 & -6.45 & -2.51 & 8.84 & .13 \\
Netherlands & $1978: 2-1987: 4$ & 9.89 & 5.93 & .735 & -7.81 & 5.64 & -10.80 & 12.98 \\
Norway & $1978: 2-1987: 4$ & 12.99 & 18.86 & .322 & -19.00 & 17.55 & 2.70 & -1.25 \\
Sweden & $1970: 2-1987: 3$ & 19.43 & 3.51 & .968 & -26.04 & 16.38 & -11.23 & 20.89 \\
Taiwan & $1961: 2-1987: 3$ & 18.70 & 8.77 & .820 & -23.39 & 21.17 & -12.87 & 15.09 \\
United King. & $1955: 2-1987: 3$ & 4.62 & 4.24 & .543 & -3.08 & -5.84 & 3.72 & 5.19 \\
United States & $1948: 2-1985: 4$ & 8.72 & 3.75 & .844 & -12.32 & 12.33 & .29 & -.31 \\
\hline
\end{tabular}




\begin{tabular}{|l|l|r|r|r|r|r|r|r|}
\hline \multicolumn{7}{|c|}{ Table B3: Real Government Purchases, Log Growth Rates (Quarterly) } \\
\hline & Sample Period & Std. Dev. of Seasonals & Std. Dev. of Residuals & \multicolumn{1}{c|}{$\boldsymbol{R}^{2}$} & \multicolumn{1}{|c|}{ Q1 } & \multicolumn{1}{c|}{ Q2 } & \multicolumn{1}{c|}{ Q3 } & \multicolumn{1}{c|}{ Q4 } \\
\hline Australia & $1960: 2-1987: 3$ & 8.78 & 3.71 & .849 & -8.69 & 11.37 & -8.25 & 5.57 \\
Canada & $1961: 2-1987: 3$ & 5.86 & 3.55 & .731 & 4.05 & -10.01 & 3.27 & 2.70 \\
Finland & $1970: 2-1987: 2$ & 4.38 & 3.60 & .597 & -5.19 & 2.77 & 5.61 & -3.19 \\
Germany & $1960: 2-1987: 3$ & 7.02 & 2.46 & .891 & -11.07 & 2.26 & .40 & 8.42 \\
Italy & $1970: 2-1984: 4$ & 4.74 & 3.67 & .625 & -7.09 & -.22 & .1 .10 & 6.21 \\
Japan & $1965: 2-1987: 3$ & 5.79 & 2.25 & .869 & -1.64 & 3.12 & -8.43 & 6.95 \\
Norway & $1978: 2-1987: 4$ & .64 & 2.76 & .051 & -.89 & .75 & -.30 & .43 \\
Taiwan & $1961: 2-1987: 3$ & 6.02 & 6.84 & .436 & -4.57 & 6.78 & -7.15 & 4.94 \\
United King. & $1955: 2-1987: 3$ & 1.09 & 1.27 & .428 & .73 & -1.58 & -.40 & 1.25 \\
United States & $1948: 2-1985: 4$ & 3.78 & 3.53 & .535 & -6.46 & 3.23 & 1.25 & 1.97 \\
\hline
\end{tabular}

\begin{tabular}{|l|c|c|c|c|r|r|r|r|r|}
\hline \multicolumn{9}{|c|}{ Table B4: Real Exports, Log Growth Rates (Quarterly) } \\
\hline & Sample Period & Std. Dev. of Seasonals & Std. Dev. of Residuals & \multicolumn{1}{|c|}{$R^{2}$} & \multicolumn{1}{c|}{ Q1 } & \multicolumn{1}{c|}{ Q2 } & \multicolumn{1}{c|}{ Q3 } & \multicolumn{1}{c|}{ Q4 } \\
\hline Argentina & $1977: 2-1987: 2$ & 17.54 & 10.39 & .740 & 10.32 & 20.36 & -5.38 & -25.31 \\
Australia & $1960: 2-1987: 3$ & 2.86 & 6.19 & .176 & -2.20 & 2.59 & -3.42 & 3.03 \\
Austria & $1973: 2-1987: 3$ & 9.18 & 5.28 & .751 & -.19 & 2.19 & 11.78 & -13.77 \\
Canada & $1961: 2-1987: 3$ & 8.54 & 5.59 & .700 & -10.39 & 13.11 & -2.86 & .13 \\
Finland & $1970: 2-1987: 2$ & 6.47 & 6.98 & .462 & -9.88 & 1.14 & .48 & 8.26 \\
Germany & $1960: 2-1987: 3$ & 4.84 & 3.51 & .655 & -7.09 & 2.05 & -1.17 & 6.21 \\
Italy & $1970: 2-1984: 4$ & 9.81 & 7.27 & .645 & -14.67 & 8.58 & -3.26 & 9.35 \\
Japan & $1965: 2-1987: 3$ & 6.54 & 3.97 & .731 & -11.08 & 5.94 & 2.49 & 2.65 \\
Norway & $1978: 2-1987: 4$ & 5.61 & 7.39 & .366 & -3.73 & .37 & -5.44 & 8.80 \\
Sweden & $1970: 2-1987: 3$ & 8.90 & 4.64 & .787 & -8.13 & 3.95 & -8.54 & 12.72 \\
Taiwan & $1961: 2-1987: 3$ & 8.17 & 11.40 & .339 & -8.20 & 13.11 & -.00 & -4.91 \\
United King. & $1955: 2-1987: 3$ & 2.37 & 4.46 & .220 & -3.04 & 2.76 & -1.51 & 1.78 \\
United States & $1948: 2-1985: 4$ & 5.12 & 5.21 & .492 & -2.47 & 4.29 & -7.14 & 5.32 \\
\hline
\end{tabular}

\begin{tabular}{|l|c|c|r|r|r|r|r|r|}
\hline \multicolumn{9}{|c|}{ Table B5: Real Imports, Log Growth Rates (Quarterly) } \\
\hline & Sample Period & Std. Dev. of Seasonals & Std. Dev. of Residuals & \multicolumn{1}{|c|}{$R^{2}$} & \multicolumn{1}{c|}{ Q1 } & \multicolumn{1}{c|}{ Q2 } & \multicolumn{1}{c|}{ Q3 } & \multicolumn{1}{c|}{ Q4 } \\
\hline Argentina & $1977: 2-1987: 2$ & 4.90 & 10.67 & .174 & .41 & -6.74 & 6.76 & -.43 \\
Australia & $1960: 2-1987: 3$ & 2.71 & 5.75 & .181 & -.42 & 1.30 & 3.22 & -4.11 \\
Austria & $1973: 2-1987: 3$ & 5.74 & 3.77 & .699 & -8.92 & 6.61 & 2.72 & -.41 \\
Canada & $1961: 2-1987: 3$ & 7.03 & 4.71 & .690 & -3.82 & 10.00 & -8.53 & 2.35 \\
Finland & $1970: 2-1987: 2$ & 6.95 & 8.72 & .388 & -11.36 & 2.58 & 1.31 & 7.46 \\
Germany & $1960: 2-1987: 3$ & 3.11 & 3.96 & .381 & -4.23 & 3.11 & 2.81 & -1.68 \\
Italy & $1970: 2-1984: 4$ & 9.71 & 7.38 & .634 & -11.24 & 5.29 & -7.06 & 13.01 \\
Japan & $1965: 2-1987: 3$ & 2.13 & 3.74 & .244 & -2.71 & .92 & -1.15 & 2.94 \\
Norway & $1978: 2-1987: 4$ & 5.72 & 5.96 & .479 & -7.45 & 3.14 & -3.09 & 7.41 \\
Sweden & $1970: 2-1987: 3$ & 6.73 & 4.13 & .726 & -8.24 & 2.02 & -3.65 & 9.87 \\
Taiwan & $1961: 2-1987: 3$ & 6.87 & 11.48 & .263 & -8.43 & 8.55 & -4.68 & 1.55 \\
United King. & $1955: 2-1987: 3$ & 1.64 & 3.98 & .145 & .34 & 1.90 & .38 & -2.62 \\
United States & $1948: 2-1985: 4$ & 3.06 & 5.13 & .262 & -1.18 & $\mathbf{4 . 6 9}$ & .18 & -3.69 \\
\hline
\end{tabular}




\begin{tabular}{|l|c|c|c|}
\hline \multicolumn{3}{|c|}{ Table B6: Relation Between Money and Consumption, Log Growth Rates (Quarterly) } \\
\hline & Sample Period & Coeficient & Standard Error \\
\hline Argentina & $1977: 2-1987: 2$ & .17 & $(.39)$ \\
Australia & $1960: 2-1987: 3$ & .24 & $(.05)$ \\
Austria & $1973: 2-1987: 3$ & .19 & $(.03)$ \\
Canada & $1961: 2-1987: 3$ & .42 & $(.04)$ \\
Finland & $1970: 2-1987: 2$ & 1.26 & $(.16)$ \\
Germany & $1968: 2-1987: 3$ & .65 & $(.04)$ \\
Italy & $1970: 2-1984: 4$ & -.34 & $(.15)$ \\
Japan & $1965: 2-1987: 1$ & .47 & $(.02)$ \\
Norway & $1978: 2-1987: 3$ & .08 & $(.07)$ \\
Sweden & $1978: 2-1987: 3$ & .07 & $(.07)$ \\
Taiwan & $1968: 2-1987: 3$ & .18 & $(.04)$ \\
United King. & $1963: 2-1987: 3$ & .37 & $(.11)$ \\
United States & $1948: 2-1985: 4$ & .11 & $(.01)$ \\
\hline
\end{tabular}

Table B7: Relation Between GDP and Employment, Log Grovrth Rates (Quarterly) Establishment Survey

\begin{tabular}{|l|c|c|c|}
\hline & Sample Period & Coefficient & Standard Error \\
\hline Austria & $1973: 2-1987: 3$ & 2.19 & $(.29)$ \\
Canada & $1965: 2-1987: 3$ & 1.69 & $(.08)$ \\
Finland & $1970: 2-1987: 2$ & .39 & $(.16)$ \\
Germany & $1965: 2-1987: 3$ & 5.01 & $(.52)$ \\
Italy & $1970: 2-1984: 4$ & 3.77 & $(.80)$ \\
Japan & $1965: 2-1987: 1$ & 13.34 & $(2.15)$ \\
Sweden & $1970: 2-1987: 3$ & -4.61 & $(.58)$ \\
United King. & $1965: 2-1987: 2$ & 4.51 & $(.97)$ \\
United States & $1948: 2-1985: 4$ & 3.30 & $(.11)$ \\
\hline
\end{tabular}

Table B8: Relation Between GDP and Employment, Log Growth Rates (Quarterly) Household Survey

\begin{tabular}{|l|c|c|c|}
\hline & Sample Period & Coefficient & Standard Error \\
\hline Australia & $1965: 2-1987: 3$ & 9.88 & $(2.21)$ \\
Austria & $1973: 2-1987: 1$ & 5.40 & $(.88)$ \\
Canada & $1965: 2-1987: 3$ & 1.59 & $(.07)$ \\
Finland & $19: 0: 2-1987: 2$ & .28 & $(.16)$ \\
Germany & $1965: 2-1987: 3$ & 5.53 & $(.58)$ \\
Italy & $1970: 2-1984: 4$ & 2.71 & $(.39)$ \\
Japan & $1965: 2-1987: 1$ & .94 & $(.17)$ \\
Sweden & $1970: 2-1987: 3$ & -4.71 & $(.47)$ \\
United States & $1948: 2-1985: 4$ & 3.34 & $(.24)$ \\
\hline
\end{tabular}




\section{Recent Crest Working Papers}

88-1: Carol A. Jones, Suzanne Scotchmer, "The Social Cost of Uniform Regulatory Standards in a Ilierarchical Government" Dccember, 1987.

88-2: Ted Bergstrom, Judy Roberts, Dan Rubinfeld, Perry Shapiro, "A Test for Efficiency in the Supply of Public Education" December 12, 1987.

88-3: Mark Bagnoli, J. Bradley Barbeau, "Competition and Product Line Choice" February, 1988.

88-4: Severin Borenstein, Paul N. Courant, "How to Carve a Medical Degree: Human Capital Assets in Divorce Settlements" December, 1987.

88-5: Mark Bagnoli, Stephen W. Salant, Joseph E. Swierzbinski, "Pacman Refutes the Coase Conjecture: Durable-Goods Monopoly with Discrete Demand" January, 1988.

88-6: Jonathan Cave, Stephen W. Salant, "A Median Choice Theorem" December 29, 1987.

88 7: Mark Bagnoli, Naveen Khanna, "Why Are Buyers Represented by Seller's Agents When Buying a IIouse?" December, 1987.

88-8: Mark Bagnoli, Roger Gordon, Barton L. Lipman, "Takeover Bids, Defensive Stock Repurchases, and the Efficient Allocation of Corporate Control" October, 1987.

88-9: Mark Bagnoli, Barton L. Lipman, "Private Provision of Public Goods can be Efficient" November, 1987.

88-10: Michelle J. White, "Urban Commuting Journeys are Not "Wasteful"” February, 1988.

88-11: A very Katz, "A Note on Optimal Contract Damages When Litigation is Costly" February, 1988.

88-12: Ted Bergstrom, Jeffrey K. MacKie-Mason, "Notes on Peak Load Pricing" February, 1988.

88-13: Jerry A. Hausman, Jeffrey K. MacKie-Mason, "Price Discrimination and Patent Policy" February, 1988.

89-01: Mark Bagnoli, Severin Borenstein, "Carrot and Yardstick Regulation: Enhancing Market Performancc with Output Prizes" October, 1988.

89. 02: 'Jed Bergstrom, Jeffrey K. MacKie-Mason, "Some Simple Analytics of Pcak-Load Pricing" October, 1988.

89-03: Ken Binmore, "Social Contract I: Harsanyi and Rawls" June, 1988.

89-04: Ken Binmore, "Social Contract II: Gauthier and Nash" June, 1988.

89-05: Ken Binmore, "Social Contract III: Evolution and Utilitarianism" June, 1988.

89-06: Ken Binmore, Adam Brandenburger, "Common Knowledge and Game Theory" July, 1988.

89-07: Jeffrey A. Miron, "A Cross Country Comparison of Seasonal Cycles and Business Cycles" November, 1988.

89-08: Jeffrey A. Miron, "The Founding of the Fed and the Destabilization of the Post-1914 Economy" August, 1988.

89-09: Gerard Gau det, Stephen W. Salant, "The Profitability of Exogenous Output Contractions: A ComparaliveStatic Analysis with Application to Strikes, Mergers and Export Subsidies" July, 1988.

89-10: Gerard Gaudet, Stephen W. Salant, "Uniqueness of Cournot Equilibrium: New Results from Old Methods" A ugust, 1988.

89 -11: Hal R. Varian, "Goodness-of-Fit in Demand Analysis" September, 1988.

89) 12: M ichelle J. White, "Legal Complexity" October, 1988.

89) 13: Michelle J. White, "An Empirical 'Test of the Efficiency of Liability Rules in Accident Law" November, 1988 .

89-14: Carl P. Simon, "Some Fine-Tuning for Dominant Diagonal Matrices" July, 1988. 


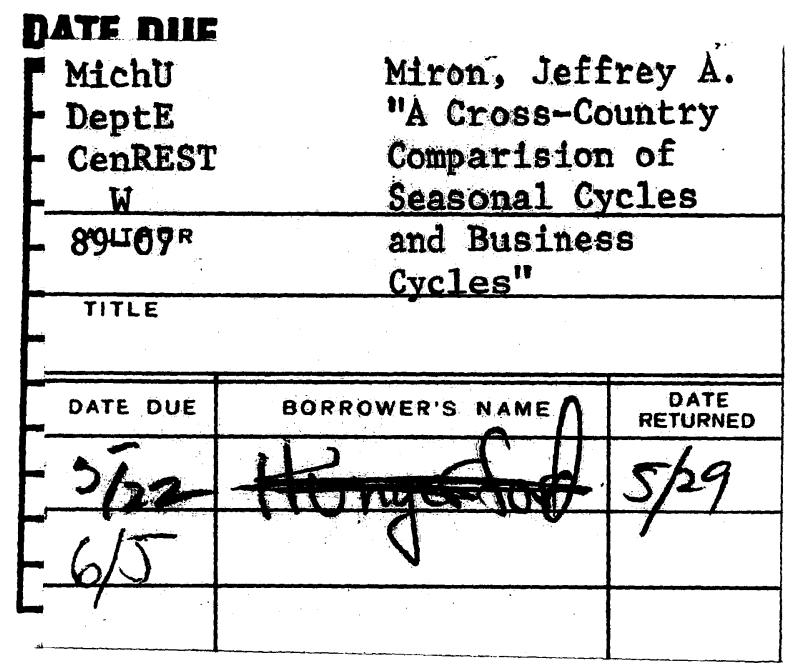


